\title{
Edição \& Censura: a materialidade dos panfletos de Sir Roger L'Estrange no início dos anos 1660
}

Edition \& Censorship: the materiality of Sir Roger L'Estrange's pamphlets in the early 1660s

hitps://doi.org/10.1590/1982-02672020v28d3e24

\section{VERÔNICA CALSONI LIMA'}

https://orcid.org/0000-0002-4090-9476

Universidade de São Paulo / São Paulo, SP, Brasil

RESUMO: Sir Roger L'Estrange foi um autor, panfletista, jornalista, tradutor e censor, cujas atividades tiveram grande impacto no desenvolvimento dos sistemas de controle da imprensa no período da Restauração de Carlos II ao trono da Inglaterra. Associando seu posto de Surveyor of the Press aos seus escritos, L'Estrange perseguiu os opositores do governo por meio de suas ações repressoras e de sua ágil pena. Seus panfletos e jornais impressos dedicavam-se a denunciar os abusos cometidos por autores, impressores e livreiros sediciosos que produziam e dispersavam textos contra o rei e a igreja, visando agitar o povo a iniciar uma nova revolução. A composição de suas obras, que comumente dependia do trabalho de seu livreiro e aliado Henry Brome, era peculiar. Seus textos congregavam fontes romanas, itálicas, góticas, notas marginais e sinais tipográficos variados. Essa multiplicidade de tipos e elementos gráficos tinha profundas consequências na transmissão e compreensão de suas mensagens, pois combinavam escrita/leitura, visualidade e oralidade. Embora essa composição não fosse estranha ao gênero polêmico, empregado para combater adversários políticos e religiosos, parece-nos possível afirmar que Roger L'Estrange tinha um estilo tipográfico particular que servia aos seus objetivos repressores. Por meio da análise material e textual de seus panfletos publicados no início dos anos 1660, pretendemos discutir as implicações da função de autor-censor desempenhada por L'Estrange no contexto da Restauração.

1. Doutoranda em História Social pela Universidade de São Paulo (USP). Possui bacharelado, licenciatura e mestrado em História pela Universidade Federal de São Paulo (Unifesp). E-mail: <veronica.calsoni@usp.br> 
PALAVRAS-CHAVE: Censura. Polêmicas. Imprensa. Panfletos. História do Livro. História da Inglaterra.

ABSTRACT: Sir Roger l'Estrange was an author, pamphleteer, journalist, translator and censor, whose activities had a great impact on the development of press control systems in the period of Charles II's Restoration to the English throne. Combining both his role as the Surveyor of the Press and his writings, L'Estrange persecuted opponents of the government by means of his repressive actions and his agile pen. His printed pamphlets and newspapers were dedicated to denouncing the abuses committed by seditious authors, printers and booksellers, who produced and dispersed texts against the king and the Church aiming to agitate the people towards a new revolution. The composition of his writings, which commonly depended on the work of his bookseller and ally Henry Brome, was peculiar. His texts congregated Roman, Italic and Gothic typefaces, marginal notes and a variety of typographical signs. This multiplicity of fonts and graphic elements had important consequences on the transmission and comprehension of his messages since it associated writing/reading, visuality and orality. Even though this structure was not unusual for the polemic genre, employed to combat political and religious adversaries, it seems possible to affirm that Roger L'Estrange had a particular typographical style, which was convenient to his repressive objectives. By analyzing the materiality and textuality of his pamphlets published at the beginning of the 1660s, this article aims to discuss the implications of the author-censor role performed by L'Estrange during the Restoration.

KEYWORDS: Censorship. Polemics. Printing Press. Pamphlets. Book History. English History. 
Um bom Compositor também tem a ambição de tornar o sentido de seu Autor inteligível ao Leitor, assim como de fazer seu Trabalho parecer gracioso aos Olhos, e agradável à Leitura: Portanto se a sua Cópia está Escrita em uma Língua que ele entende, ele lê sua Cópia com consideração; a fim de compreender o sentido do Autor, e consequentemente considerar como melhor ordenar o seu Trabalho tanto na Folha de Rosto, como no assunto do Livro: Assim como fazer seu Recuo, Pontuação, Quebra, Itálico, \&c. para melhor acomodar o Gênio do Autor, e também a capacidade do Leitor. ${ }^{3}$

Em seu manual de impressão, Joseph Moxon registrava práticas já conhecidas no mercado livreiro. ${ }^{4}$ Talvez por essa razão, sua obra ricamente ilustrada e detalhada não tenha feito tanto sucesso em sua época. Por um lado, compositores, tipógrafos, livreiros e outros agentes do mundo dos impressos já conheciam as técnicas expostas por Moxon; por outro, pessoas de camadas mais abastadas talvez não tivessem grande interesse nos ensinamentos de artes manuais como a tipografia. ${ }^{5}$ Sua obra, contudo, nos forneceu importantes detalhes sobre os processos de impressão e edição de textos na Inglaterra da Época Moderna. Ela é evidência de que as decisões acerca da disposição do texto na página eram feitas na oficina tipográfica, sem que os autores tivessem grande autonomia a respeito dessas escolhas. $\bigcirc$ uso de itálicos, góticos, espaçamentos e sinais gráficos era, em sua maioria, decorrente das preferências dos compositores, impressores e livreiros que intermediavam as relações estabelecidas entre o texto escrito pelo autor e o que chegava ao leitor. ${ }^{6}$

Embora essas afirmações possam nos levar a acreditar em um papel diminuto do autor frente ao seu próprio escrito, é preciso considerar que a produção de um impresso era coletiva, contando com a participação e a negociação de diferentes agentes. ${ }^{7}$ Alguns autores parecem ter tido maior poder de barganha, intervindo diretamente no processo de publicação de suas obras. Esse era o caso do panfletista, jornalista, tradutor e censor Sir Roger L'Estrange (1 616 6-1704). Seus textos são facilmente reconhecidos devido à curiosa disposição dos elementos gráficos na página. Comumente, a composição de suas obras demandava o uso de tamanhos e tipos diferentes de fontes, e uma variedade de sinais gráficos, como pode ser visto na figura 1. Ênfases eram marcadas com maiúsculas iniciais ou caixas altas na palavra toda; itálicos também podiam ser empregados e, para destaques ainda mais dramáticos, fontes góticas eram utilizadas. Citações literais apareciam em itálico, e, quando eram muito longas, por vezes, também contavam com espaçamento diverso, ficando em blocos separados do texto principal. Notas
2. Faz-se necessário agradecer ao financiamento concedido pela Fundação de Amparo à Pesquisa do Estado de São Paulo (Fapesp) (processos $n^{\circ} 2017 / 06970-2$ e 2018/03730-3), e ao apoio da Chetham's Library, que me acolheu como visiting fellow entre 2018 e 2019 , facilitando meu acesso a seu rico acervo. Agradeço também aos comentários e às sugestões que recebi de: Luís Filipe Silvério Lima, Ariel Hessayon, Ana Paula Torres Megiani, Fergus Wilde, Grace Timperley, Jaime Fernando dos Santos Junior, Bruna Braga Fontes, Lívia Bernardes Roberge, Michelle Mayumi Hachisu, Aline Davies Moreira, Vinícius Ayres dos Santos, Mariana Stefanny Moises Duzzi, Victoria Rodrigues, Jéssica Lury e Jonathan Portela.

3. No original: "A good Compositer is ambitious as well to make the meaning of his Author intelligent to the Reader, as to make his Work shew graceful to the Eye, and pleasant in Reading: Therefore if his Copy be Written in a Language he understands, he reads his Copy with consideration; that so he may get himself into the meaning of the $A u$ thor, and consequently considers how to order his Work the better both in the Title Page, and in the matter of the Book: As how to make his Indenting, Pointing, Breaking, Italicking, Ec. the better sympathize with the Authors Genius, and also with the capacity of the Reader." Moxon (1683, p. 220).

4. Acerca de manuais tipográficos da Época Moderna, cf. o recente artigo de Araújo (2020).

5. Cf. Davis e Carter (1958).

6. Cf. Chartier ( 2014).

7. Cf. Johns (1998) 
8. Cf. L'Estrange (1661a). Imagem reproduzida com a permissão da Chetham's Library, Manchester (Reino Unido).

9. Estacionário era o termo utilizado para se referir aos diversos agentes do mercado livreiro londrino. Tratavam-se dos compositores, tipógrafos, encadernadores e livreiros participantes da Companhia dos Estacionários (Stationers' Company), que regulava a produção $\mathrm{e}$ a comercialização de impressos desde o século XVI.

10. No século XVII, não existia a figura do editor enquanto um profissional autônomo; sua função, contudo, era exercida por impressores e/ou livreiros que detinham os direitos de cópia das obras, e ocupavam-se da mediação entre o escrito do autor e o texto que circularia entre os leitores. Cf. Mollier (2009). marginais, com ou sem sinais gráficos (como asteriscos, chaves, colchetes, parênteses, cruzes, pontos, manículas ou aspas), eram frequentes.

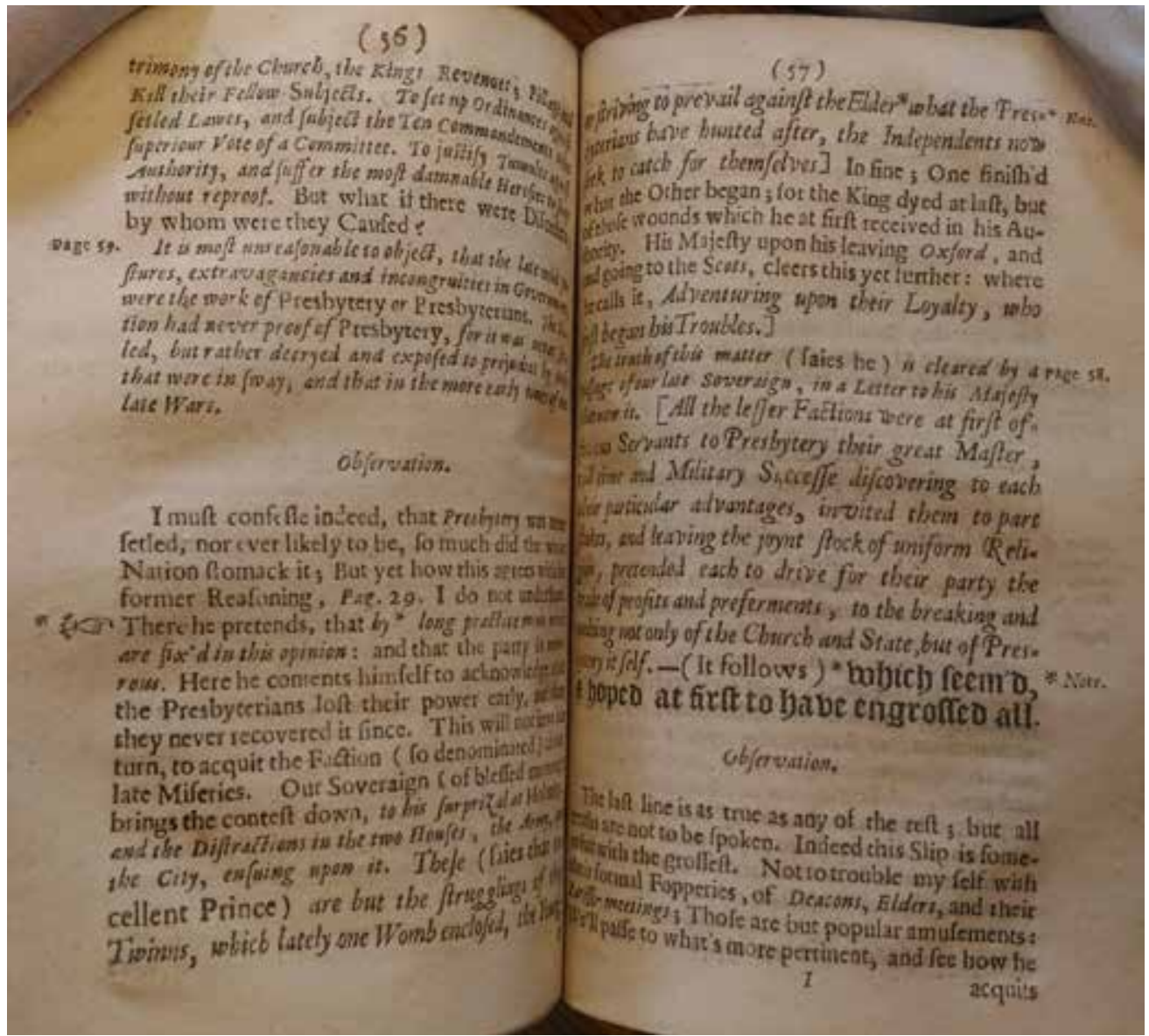

Figura 1 - Trecho de Interest Mistaken, or, The Holy Cheat (1661).8

Acreditamos que as suas engenhosas composições não eram apenas oriundas do trabalho de seus estacionários, ${ }^{9}$ mas de suas determinações e interferências diretas no processo editorial. Além de ter considerável poder no mercado livreiro inglês do período da Restauração devido ao seu posto de Surveyor of the Press, L'Estrange tinha conhecimento sobre as artes do livro, bem como contava com o intenso diálogo com seu livreiro-editor, ${ }^{10}$ Henry Brome (c. 1620-16811. Essas condições certamente tiveram impacto em sua produção impressa. Neste artigo, pretendemos examinar a justaposição entre os papéis de censor e autor de Roger L'Estrange por meio da análise textual e material de alguns de seus panfletos publicados no início da década de 1660, período em que iniciou sua carreira nos sistemas de regulação da imprensa. 
Argumentamos que a posição ocupada por L'Estrange no mercado livreiro era privilegiada. Enquanto autor-censor, ele participava do mundo do livro duplamente, como um agente interno que escrevia e publicava seus textos, e um agente externo que se colocava acima dos demais sujeitos que participavam da produção e da disseminação das obras impressas. Ele vigiava, denunciava e punia em seus escritos e em suas intervenções diretas. Acreditamos que esse posicionamento, aliado à sua profícua relação com Henry Brome, seja uma das razões principais para que ele desenvolvesse um estilo tipográfico tão incomum.

Nosso exercício de análise acerca da materialidade de suas obras nos permite perceber que a potência de seus escritos em muito dependia desse estilo, pois a tipografia de seus panfletos congregava escrita/leitura, visualidade e oralidade. ${ }^{11}$ Os recursos gráficos empregados por L'Estrange e Brome representavam os embates político-religiosos nos quais o autor-censor pretendia interferir. Por um lado, a profusão tipográfica guiava a leitura, afetando lou tentando afetar) a compreensão e a interpretação do público. Por outro, os diferentes tamanhos e tipos de fonte, os espaçamentos e os símbolos expressavam ênfases e diferenciavam as várias vozes que compunham seus textos, nos quais citações de seus opositores eram frequentemente evocadas para articular um acalorado debate. Além disso, as marcas de oralidade eram fundamentais, com pontuações e sinais gráficos que sugeriam ao leitor como reproduzir as entonações pretendidas para que os ouvintes melhor compreendessem a mensagem.

A fim de discutirmos os elementos dessa tríade comunicativa (escrita/ leitura, visualidade e oralidade) - para empregar o termo de Fernando Bouza ${ }^{12}$ -, e os efeitos pretendidos com o uso desse estilo tipográfico, nosso artigo está dividido em cinco partes. Em um primeiro momento, faz-se necessário apresentar a trajetória biográfica de Roger L'Estrange e o conturbado contexto político-social em que viveu. Esse preâmbulo é importante para situar a produção e as atividades do autor, e para compreender a construção de sua persona como censor, pois mesmo antes de ser nomeado para o cargo, seus textos exprimiam um tom crítico e repressor contra aqueles que ele julgava serem inimigos do governo e da igreja. Após essa contextualização, as partes seguintes enfocam exames materiais e textuais de suas obras. Para essas análises, pautamo-nos, sobretudo, nas técnicas e discussões da Bibliografia Material e da História do Livro, segundo as quais "o sentido que o texto transmite é crucialmente afetado pela forma material do livro $[\ldots]^{\prime \prime}, 13$ do panfleto, do jornal ou de qualquer outro escrito. A partir disso, a segunda seção introduz reflexões sobre o estilo tipográfico de L'Estrange, lançando luz sobre a oralidade expressa em seus textos. A terceira parte se dedica a discutir publicações polêmicas, tão recorrentes entre as obras de
11. Cf. Bouza (2002).

12. Ibid.

13. No original: "The meaning that the text conveys is crucially affected by the material form of the book [...]" Raven (2017, posições 493494). 
14. Entre 1640 e 1660 , a Inglaterra viveu um período de profunda crise política, social e econômica. Em 1641, Carlos I e seu Parlamento entraram em um grave conflito que desembocou em duas Guerras Civis (1642-1646 e 1648-1649) e na queda da monarquia. Diversas foram as causas dos desgastes das relações entre o rei e os parlamentares, mas uma das principais era $\mathrm{O}$ fato de Carlos I ter reinado por 11 anos sem convocar a assembleia para tomar decisões. Quando chamado para autorizar a arrecadação de impostos para financiar os exércitos que continham rebeliões na Irlanda e na Escócia, o Parlamento negou as demandas do rei e foi dissolvido. Carlos I perseguiu os líderes da oposição parlamentar e um conflito armado começou a se configurar. O Parlamento saiu vitorioso e, em 1649, levou o monarca à julgamento, condenando-o e executando-o por alta-traição contra o povo inglês. A partir de então as mudanças de governo foram frequentes. A Inglaterra passou por uma república (16491653), um Protetorado (1653-1659), uma nova república (1659) e, finalmente, retornou à monarquia (1660). Os debates acerca do contexto revolucionário são extensos. Questões ligadas à política, à economia, à cultura, à religião, e à situação da população no campo e na cidade foram sublinhadas por diferentes historiadores que procuraram demarcar os motivos que levaram à intensa convulsão social das décadas de 1640 a 1660 . Desde os anos 1970, com a chamada historiografia "revisionista", as explicações macroeconômicas ou sociais das causas de desenvolvimento da Revolução Inglesa, características das interpretações "whig-
L'Estrange. Sendo um gênero combativo, a polêmica era mobilizada pelo autor para criticar seus adversários. Utilizando muitas citações literais, elas frequentemente demandavam o uso de fontes e símbolos que pudessem representar um verdadeiro embate entre autores. $\bigcirc$ amplo uso desse gênero era uma das razões pelas quais a visualidade era tão importante nas obras de L'Estrange, por isso, nossa quarta parte se aprofunda no exame bibliográfico dos recursos tipográficos empregados pelo autor e seu livreiro. Por fim, elencamos algumas considerações a respeito da imbricação entre suas funções de autor e censor.

\section{DE CONDENADO A CENSOR}

Na historiografia de língua inglesa, Roger L'Estrange é recorrentemente citado quando a censura e a Restauração da monarquia são abordadas. De fato, sua presença foi marcante na época. L'Estrange participou ativamente dos debates político-religiosos acerca do retorno da dinastia Stuart, bem como dos processos de reestruturação dos instrumentos de controle da imprensa na Inglaterra. Desde que Carlos II recuperou o trono em 1660, depois dos 20 anos de intensa agitação política e social da Revolução Inglesa ${ }^{14}$, L'Estrange ressaltou a importância de controlar as publicações impressas. ${ }^{15}$

Entre as décadas de 1640 e 1660, o mercado livreiro se desenvolvera com poucos constrangimentos. Os conflitos entre Carlos I e o Parlamento, o esfacelamento da monarquia, a supressão da Star Chamber $^{16}$ e da High Commission, ${ }^{17}$ e as constantes alternâncias de governo proporcionaram um ambiente conveniente para o crescimento vertiginoso do número de publicações e da circulação de textos impressos. Não é à toa que foi durante esse período que a produção e a comercialização de gêneros efêmeros se tornaram mais expressivas. Panfletos, petições e jornais eram emitidos frequentemente para relatar os acontecimentos e exprimir opiniões diversas a respeito das turbulências vividas pela Inglaterra. ${ }^{18}$ Embora a Commonwealth (1649-1653) e, posteriormente, o Protetorado (1653-1659) tenham tentado implementar medidas de controle da imprensa, elas não foram capazes de conter a profusão de textos em produção e circulação. A atuação dos instrumentos de censura durante a Revolução Inglesa tendeu a suprimir e punir casos específicos, mas não conseguiu firmar uma estrutura que cerceasse efetivamente a emissão e a disseminação de obras que confrontassem as autoridades no poder. ${ }^{19}$

A experiência revolucionária de outrora tornava evidente a urgência em colocar freios na imprensa para consolidar a estabilidade da nova monarquia. 
Embora Carlos II não tenha promulgado leis imediatamente após a sua coroação, com frequência ele emitiu decretos especificamente direcionados à supressão de panfletos sediciosos - como Pro Populo Anglicano Defensio, do poeta republicano John Milton, e Obstructers of Justice, do ministro religioso independentista John Goodwin -, visando silenciar aqueles que ainda propagandeavam a favor da república e/ou rejeitavam a volta ao regime monárquico. ${ }^{20}$ Segundo L'Estrange, o estabelecimento de uma política rigorosa contra produtores de literatura sediciosa era imprescindível, pois eles pretendiam "[...] desassossegar o Povo contra a Pessoa e o Governo da Vossa Majestade; e seu próximo Negócio é Encorajar, e Conduzir essas Inclinações Sediciosas à Ação" . ${ }^{21}$ Para o autor, a imprensa tinha o poder de desestruturar o governo. Sendo assim, para garantir a manutenção da ordem, era preciso intervir.

Muitas das propostas de regulamentação da imprensa feitas por Roger L'Estrange foram adotadas, sobretudo quando ele assumiu o posto de Surveyor of the Press em agosto de 1663. No entanto, o seu caminho até o cargo não foi simples e linear. $\bigcirc$ autor precisou construir as bases para a sua atuação como protetor da ordem. É preciso, portanto, entender suas atividades e seus posicionamentos públicos até sua efetiva ascensão ao posto de censor. ${ }^{22}$

Apesar de alegar sempre ter sido leal à monarquia, a trajetória de L'Estrange durante o contexto revolucionário foi escusa. Ainda no início das Guerras Civis entre o rei e o Parlamento, em agosto de 1643, ele se juntou ao exército regalista na defesa da cidade portuária de King's Lynn, localizada no condado de Norfolk. Seus esforços não tiveram sucesso, e a cidade foi invadida pelas forças parlamentares após seis semanas de conflito. Em 1644, L'Estrange foi para a corte estabelecida em Oxford e conseguiu um mandato para a recaptura da cidade. A estratégia era subornar o exército do Parlamento e retomar o controle de King's Lynn. Contudo, o plano de L'Estrange foi descoberto por um espião parlamentarista. Ele acabou sendo preso e levado para Londres, onde foi julgado e condenado por espionagem e conspiração. Foi sentenciado à forca, mas conseguiu apelar da decisão, permanecendo preso em Newgate. ${ }^{23}$

Em 1648, escapou do cárcere e se juntou às forças regalistas que se rebelavam em Kent. $\bigcirc$ condado - controlado pelo Parlamento desde 1642 - revoltou-se quando, em dezembro de 1647, foi reforçada a proibição das celebrações natalinas. Baseado em fortes ideais puritanos, o Parlamento considerava o Natal uma festividade papista sem fundamento, uma vez que a data do nascimento de Cristo não podia ser comprovada. $\bigcirc$ impedimento da realização das festividades desagradou a muitos, desencadeando protestos e rebeliões. Com grande apelo popular, a sublevação gistas" e marxistas, foram duramente atacadas, propondo-se, no lugar, leituras com foco na análise detida dos eventos políticos, inclusive recusando o uso da expressão "Revolução Inglesa”. Essas narrativas "revisionistas", predominantes até inícios dos anos 1990, por sua vez, vêm sendo revistas, com trabalhos que têm pensado a Cultura Política e os diferentes agentes envolvidos nos eventos que novamente têm sido enquadrados sob a denominação "Revolução Inglesa". Sobre o debate historiográfico, cf. entre outros Pujol (1997), Richardson (1998), Stone (2000), Russel (1973), Ostrensky (2005), Hill (1987), Hill (2012), Worden (2009), Keeble (2001), Woolrych (2002).

15. Cf. por exemplo Keeble (2002), Hutton (2001), Harris (2006).

16. A Star Chamber ou Câmara Estrelada era uma corte suplementar do sistema jurídico da Inglaterra. Durante o governo de Carlos I, foi vista como uma instituição repressiva, que implementava medidas políticas e eclesiásticas impopulares. Embora a historiografia tenha associado sua queda a uma completa dissolução dos sistemas de censura, a Câmera Estrelada não atuava frequentemente em casos relacionados ao mercado livreiro. Talvez o episódio mais emblemático ligado à imprensa tenha sido a condenação de William Prynne pela publicação de Histriomastix (1632), que ofendera à rainha Henriqueta $\mathrm{Ma}$ ria. Ainda que a corte não estivesse tão relacionada a uma regulamentação da imprensa, há de se considerar que sua destituição tenha impactado na censura de ideias sediciosas. Cf. Hill (2012), Clegg (2010) 
17. A High Commission era uma corte eclesiástica criada por Elizabeth I para garantir uniformidade religiosa. Como apontado por Cyndia Clegg, também não tinha grande atuação na regulamentação da imprensa, mas sua dissolução afrouxou o controle da disseminação de pensamentos e escritos heterodoxos. Cf. Hill (2012), Clegg (2010).

18. Cf. Raymond (2004), Achinstein (2001), Smith (1997), Barnard, McKenzie e Bell (2002).

19. Sobre a censura na Inglaterra ao longo do século XVII, cf. Clegg (2010), McElligott (2012), Raymond (2017), Hamburger (1985), Dzelzainis (2017).

20. Cf. By the king... (1660).

21. No original: "[...] to disaffect the People toward Your Majesties Person and Government; and their next Business is to Encourage, and Carry on these Seditious Inclinations into Action." L'Estrange (1663, fl. 3).

22. Cf. Lynch (2008), Love (2007), Taylor (2011).

23. Cf. Lynch (2008), Kitchin (1913), Love (2007), Taylor (2011).

24. Taylor (2011).

25. Cf. Lynch (2008), Kitchin (1913), Love (2007), Taylor (2011).

26. L'Estrange (1649).

27. Cf. Lynch (2008), Kitchin (1913), Love (2007), Taylor (2011).

28. Cf. Lynch (2008), Taylor (2011). adquiriu contornos monarquistas, e L'Estrange, provavelmente, acreditou que aquela era uma nova oportunidade para que as forças de Carlos I retomassem o poder. ${ }^{24}$

O Parlamento tentou negociar uma trégua com os habitantes de Kent, conseguindo que muitos dos agitadores se rendessem. Ainda assim, a convulsão social no condado não foi efetivamente contida. Novas revoltas foram organizadas, forçando o exército parlamentar a admitir posturas mais rigorosas. Kent foi controlado apenas em junho de 1648, depois da investida comandada por Lorde Thomas Fairfax. Consequentemente, L'Estrange acabou preso novamente. ${ }^{25}$

Embora não tenha participado ativamente dos conflitos - na verdade, ele sequer parece ter pego em armas -, o autor escreveu L'Estrange His Vindication From the Calumnies of a Malitious Party in Kent, ${ }^{26}$ atribuindo a si mesmo um papel central. $O$ texto the garantiu as simpatias de regalistas poderosos como Edward Hyde, primeiro Conde de Clarendon, os quais conseguiram fazer com que ele saísse da Inglaterra em segurança, refugiando-se na Holanda. Permaneceu no exílio enquanto a monarquia ruía, e Carlos I era destituído e executado. ${ }^{27}$

Seu retorno a Londres apenas foi possível em 1653, quando o governo inglês se tornou um Protetorado, liderado pelo General Oliver Cromwell. O Protetor iniciou uma política de acomodação, na qual tentou se reconciliar com antigos defensores de Carlos I. L'Estrange se aproveitou da situação, regressando e pedindo a nulidade de sua antiga condenação à morte. Cromwell, aparentemente, interviu pessoalmente, inclusive recebendo L'Estrange no Palácio de Whitehall. O Protetor the concedeu o perdão sob a promessa de que não causaria nenhum mal ao regime, nem deturparia a ordem. O período em que L'Estrange viveu sob o governo cromwelliano parece ter passado sem agitações, o que o levou, posteriormente, a ser considerado por muitos regalistas como um vira-casacas. ${ }^{28}$

Foi apenas após a morte de Oliver Cromwell, em setembro de 1658, que L'Estrange voltou a publicitar suas perspectivas políticas, advogando em favor da dissolução do Parlamento e do retorno da monarquia. Seu silêncio poderia ser decorrente de certa conformidade com o governo do Lorde Protetor, mas também poderia estar relacionado ao intenso combate ao regalismo nos últimos anos de Cromwell. Conspiradores monarquistas foram executados nesse contexto. Assim, não parecia prudente desafiar o Protetor que the garantira o regresso à Inglaterra, e que poderia the condenar à morte novamente. A situação, contudo, se transformou quando o filho de Oliver Cromwell, Richard, assumiu o governo. Para os críticos do Protetorado - tanto republicanos quanto regalistas -, a manobra fora vista como um atestado de que o regime não passava de outra monarquia, com o agravante de ser ilegal, conforme as declarações parlamentares de 1649, 
que impediam a manutenção de um governo de uma única pessoa, e ilegítima, de acordo com a linha sucessória da família Stuart. ${ }^{29}$

Richard Cromwell não tinha o mesmo apoio ou as mesmas habilidades políticas de seu pai. Seu governo durou poucos meses, pois ele acabou renunciando. A Inglaterra passou por uma segunda e breve experiência republicana em 1659, o que agitou os ânimos do Parlamento e da população. Foi nesse contexto que negociações para a retomada da monarquia começaram a ser encabeçadas por alguns parlamentares, que preferiam o retorno de Carlos II a uma nova turbulência político-social. Assim, em 4 de abril de 1660, foi assinada a Declaração de Breda, que articulou as condições para a volta do rei. ${ }^{30}$

L'Estrange rapidamente propagandeou seu apoio a Carlos II. Entre a segunda metade de 1659 e os primeiros instantes da Restauração em 1660, ele lançou ao menos 21 panfletos que visavam descreditar a república, condenar grupos políticoreligiosos antimonarquistas e advogar em favor do rei. ${ }^{31}$ A sua posição, contudo, fora contestada não apenas por aqueles ainda esperançosos quanto à volta da Commonwealth, mas por regalistas. $\bigcirc$ perdão concedido anteriormente por Cromwell ainda ressoava como uma possível ligação ao Protetorado. ${ }^{32}$

Procurando se defender de acusações de traição contra a família Stuart, o autor publicou, em junho de 1660, L'Estrange His Apology, no qual teceu sua persona como um súdito leal que muito havia feito pela coroação de Carlos II. Narrando eventos desde sua participação no levante do condado de Kent em 1648 até a efetivação da Restauração, L'Estrange recapitulou sua vida como uma completa e dedicada defesa do regime monárquico. Junto aos seus relatos autobiográficos, o autor aglutinou todos os panfletos e as petições que publicara até então, elaborando uma coletânea de atestados de sua luta pela volta do soberano de direito. ${ }^{33}$

De fato, todas as suas publicações do contexto da Restauração pareciam evocar uma imagem de comprometimento, lealdade e defesa do governo, da moral, da ordem e da religião. L'Estrange sempre assumia um tom de quem estava à disposição do rei, de quem prestava serviços à sociedade. Como sugerido por Darrick Taylor, L'Estrange - assim como outros homens e mulheres da Época Moderna - agia e pensava a partir da concepção de officium (dever). Discutida por Cícero em De Officis - que, inclusive, foi traduzido para o inglês por Roger L'Estrange em 1680 -, a ideia de officium relacionava-se às obrigações morais da vida pública. Ao performar seus deveres com base na honra e na virtude, o cidadão colaboraria para o bem comum. Em uma sociedade como a da Inglaterra do século XVII, a noção ligava-se à constituição de laços de fidelidade com o soberano e ao cumprimento de obrigações para com o reino, que poderiam desembocar no recebimento de privilégios e mercês. ${ }^{34}$
29. Cf. Hutton (1985), Love (2007), Taylor (2011).

30. Cf. Harris (2006), Hutton (1985), Keeble (2002).

31. Cf. Taylor (2011).

32. Cf. Lynch (2008), Taylor (2011).

33. L'Estrange (1660a).

34. Taylor (2011). 
35. Cf. Lynch (2008), Kitchin (1913), Love (2007), Taylor (2011)

\section{Cf. Woolf (2008).}

37. No original: "[...] Discovery of the Kings Enemies [...]" L'Estrange (1661b, p. 3).

38. No original: "[...] Their Gains are great, their $\mathrm{Ha}$ zzard little, beside the Pleasure of accomplishing their malice." Ibid., p. 10-11.

39. Cf. Greaves (1986) e Bell (1992).

40. No original: "[...] a virulent Pamphlet [...]" (1661b, p. 11).
L'Estrange, nesse sentido, articulava a noção de officium em todos os seus textos e ações públicas, atribuindo a si o dever de zelar pelo bem do reino por meio da imprensa e do controle dela. Ele alegava que diversos inimigos constantemente ameaçavam a estabilidade do reinado de Carlos II. Para o autor, sectários religiosos, antimonarquistas, republicanos e conspiradores (reais ou falsos) tramavam novas sublevações, usando, sobretudo, os impressos para propagandear seus ideais sediciosos. Uma imprensa livre era uma das principais ameaças à ordem e à paz, por essa razão a denúncia e a perseguição a panfletos e livros controversos eram fundamentais. L'Estrange parece ter assumido essa empreitada (ou dever), mesmo sem um cargo oficial de censor. Ele provavelmente esperava que seu engajamento o ajudasse a ascender ao posto, que poderia ser conquistado como retribuição aos seus serviços. Assim, paralelamente às suas publicações, ele passou a investigar agentes do mercado livreiro que pudessem estar envolvidos com a produção e a disseminação de impressos antirregalistas. ${ }^{35}$

Apesar de denunciar a sedição e a desordem desde 1659, foi a partir de meados de 1661 que suas investidas contra seus oponentes se intensificaram e, ao mesmo tempo, parecem ter surtido mais efeitos. Em 28 de agosto, L'Estrange publicou com Henry Brome o panfleto intitulado A Modest Plea both for the Caveat, and the Author of it. Embora o texto tivesse como foco a disputa que Roger L'Estrange nutria com o historiador e político James Howell - que reivindicava junto à coroa algum cargo em retribuição à sua lealdade (a qual era contestada por L'Estrange) ${ }^{36}$-, uma parte da obra também se dedicava a incriminar personagens do mercado livreiro londrino. No panfleto, ele relatava sua "[...] Descoberta de Inimigos do Rei [...]", ${ }^{37}$ uma confederação de impressores e livreiros sediciosos que dispersavam inúmeros libelos perigosos. Para L'Estrange, a existência do negócio era facilmente justificável, pois "Seus Ganhos são grandes, seu Risco pequeno, além do Prazer em concretizar sua malícia". ${ }^{38} \mathrm{~A}$ perniciosa associação - que L'Estrange veio a nomear como "Estacionários Confederados" (Confederate Stationers) - contava com os livreiros Giles Calvert, Thomas Brewster, Livewell Chapman e Francis Smith, conhecidos por sua associação com grupos radicais religiosos como Quakers e Homens da Quinta Monarquia, e por sua aproximação de defensores da Commonwealth, como John Milton e Henry Vane. ${ }^{39}$

L'Estrange afirmou ter identificado o grupo quando investigava a publicação de A Phenix or the Solemn League and Covenant, "[...] um Panfleto virulento [...]"40 que evocava a aliança estabelecida entre ingleses e escoceses em 1643 para derrotar Carlos I no início das Guerras Civis. A liga fora considerada ilegal a partir da coroação de Carlos II, e seus manifestos de outrora foram queimados. O grupo teria, assim, afrontado a soberania real ao tentar fazer a aliança renascer das cinzas, 
como uma fênix, publicando os textos de 1643, bem como as determinações parlamentares de 1649, que haviam extinguido os governos de uma única pessoa. ${ }^{41}$

Enquanto tentava encontrar os autores do panfleto que circulara anonimamente, L'Estrange se deparou com folhas de outro texto igualmente perigoso, Mirabilis Annus, or The Year of Prodigies, supostamente produzido pelo mesmo grupo. ${ }^{42}$ A obra se tratava de uma compilação de recentes milagres, prodígios e eventos sobrenaturais, que tentava convencer o público de que Deus enviava sinais de sua desaprovação da monarquia Stuart. Para L'Estrange, tais afirmações "[...] bastam, para Perseguições: e agora as Pessoas estão assustadas, veja que encorajamento o infeliz [texto] thes dá para se rebelarem, e rejeitarem o Jugo ". ${ }^{43}$

A acusação incitada por L'Estrange em A Modest Plea não se resumiu à escrita, impressão e circulação do panfleto lque teve três edições entre 1661 e 16621, pois paralelamente à sua redação, o autor fez suas denúncias diretamente ao Secretário de Estado, ocasionando perseguições a tipógrafos e livreiros. $\bigcirc$ impressor Thomas Creake, o primeiro dos Confederados a ser identificado, foi examinado dois meses antes da publicação de A Modest Plea, em 29 de junho. Em seu depoimento, Creake assumiu ter participado da impressão de A Phenix e Mirabilis Annus, mas dizia que o fizera a mando dos livreiros Livewell Chapman, Thomas Brewster e Giles Calvert. No mesmo dia, as autoridades entrevistaram Calvert, que tentou se desvencilhar das acusações, apontando Chapman e Brewster como os idealizadores da empreitada, e o encadernador George Thresher, que reforçou a participação dos três livreiros e mencionou a colaboração de Francis Smith. ${ }^{44}$

Apesar de sua importante contribuição para a identificação e supressão de literatura antirregalista, L'Estrange ainda não havia conquistado muitas simpatias entre as autoridades. Por essa razão, escreveu uma segunda apology em dezembro de 1661, destinada ao Conde de Clarendon, Chanceler de Carlos II, buscando atestar mais uma vez sua lealdade ao regime. ${ }^{45}$ A estratégia parece ter sido bem-sucedida, visto que em 24 de fevereiro do ano seguinte L'Estrange foi nomeado Surveyor of the Imprimery, embora sem receber vencimentos. ${ }^{46} \bigcirc$ novo posto the autorizava a "[...] de tempos em tempos fazer busca por, apreender, \& capturar todos os Autores, Idealizadores, Impressores, publicadores \& dispersores de Livros \& Libelos traidores e sediciosos [... $]^{\prime \prime}{ }^{47}$

Sua nomeação ocorria apenas alguns dias após a promulgação do Printing Act, que reconfigurou a censura na Inglaterra. $\bigcirc$ decreto determinava, entre outras coisas: a repressão da produção, comercialização, dispersão e leitura de obras contrárias à monarquia e à igreja; a proibição de publicações feitas por pessoas que não fizessem parte da Companhia dos Estacionários; a obrigatoriedade de que os textos fossem licenciados por autoridades e registrados no Entry Book da Companhia
41. A Phenix or... (1661)

42. Eniaytos terastios $\mathrm{Mi}$ rabilis... (1661).

43. No original: "[...] suffice, for Persecutions: and now the People are startled, see what encouragement the wretch gives them to rebell, and cast off the Yoke." L'Estrange (1661b, p. 13).

44. PRO SP29/28/121, 121a; PRO SP29/38/123, 124.

45. L'Estrange (1661c).

46. Cf. Lynch (2008).

47. No original: "[...] from time to time make search for, apprehend, \& seize all Authors, Contrivers, Printers, publishers \& dispersers of treasonable \& seditious Books and Libells [...]". PRO SP29/51/13. 
48. Cf. Charles II (1662).

49. Cf. L'Estrange (1662).

50. Cf. Harris (2006), Marshall (2003).

51. No original: "The most Dangerous People of all [...]" L'Estrange (1663, p. 6).

52. Ibid. antes de sua impressão e circulação; e a limitação do número de casas tipográficas em Londres, Oxford e Cambridge. Apesar de essas imposições não serem inéditas, mas sim reelaborações e reforços de leis que estiveram em vigor antes e/ou à época da Revolução Inglesa, o governo de Carlos II se empenhov em uma rigorosa efetivação das medidas, inaugurando um contexto de severo controle do mercado livreiro. ${ }^{48}$

A partir de então, a cruzada de L'Estrange contra a imprensa sediciosa passou a associar perseguição ativa à publicação dos resultados de suas investigações. Ele reforçava sua autoridade por meio da mobilização de sua persona censora em seus escritos. Com essa estratégia, em junho de 1662, ele noticiava o desenrolar de sua empreitada contra os Estacionários Confederados. Em Truth and Loyalty Vindicated, ele anunciava aos seus leitores que Giles Calvert fora preso, Chapman fugira para evitar punições e Brewster estivera ausente de Londres até então, mas agora poderia ser examinado. ${ }^{49}$ Ao mesmo tempo, mandatos de busca e apreensão, espionagens e depoimentos eram conduzidos para identificar autores, impressores e livreiros envolvidos com publicações controversas. ${ }^{50}$

Em junho de 1663, lançou uma das principais sínteses de suas reflexões sobre o controle da imprensa, Considerations and Proposals in Order to the Regulation of the Press. No panfleto, L'Estrange informou a continuidade de sua luta contra o grupo que publicara A Phenix, Mirabilis Annus e outros títulos oposicionistas, descrevendo-os como "As Pessoas mais Perigosas de todas [...]" ${ }^{51}$ Para ele, era preciso que as autoridades fossem ainda mais rigorosas, a fim de evitar a proliferação de casas impressoras clandestinas e a produção e disseminação de obras sediciosas. Endereçado a Carlos II, o texło compilava uma série de medidas que poderiam reforçar os sistemas de censura, como a atribuição de penas mais severas para infratores do Printing Acte a diminuição do poder da Companhia dos Estacionários. L'Estrange deixava claro que enquanto a fiscalização estivesse centralizada na atuação da corporação de ofício, seus interesses seriam priorizados em detrimento do cumprimento das normas. Licenças e registros continuariam sendo emitidos para textos controversos, e estacionários com condutas inadequadas permaneceriam impunes. Era preciso consolidar um poder que estivesse acima do mercado livreiro. Implicitamente, L'Estrange colocava-se como essa autoridade, que vinha se dedicando a identificar tantas obras perigosas a serem suprimidas. Para confirmar essa ideia, o autor-censor incluía em seu Considerations and Proposal uma longa lista de impressos que deveriam ser reprimidos, incluindo não apenas os textos recentemente publicados, como também os que haviam sido lançados durante o contexto revolucionário, indicando que cópias antigas ou reedições de obras que afrontassem a autoridade do rei e/ou da igreja deveriam ser proibidas. ${ }^{52}$ 
Para N. H. Keeble, foram os avanços - e podemos incluir a publicação de seus avanços - contra produtores de literatura sediciosa, como os Estacionários Confederados, que garantiram a L'Estrange sua ascensão. ${ }^{53}$ Entre 1661 e 1663, ele conseguiu identificar a intrincada rede de produção e dispersão de panfletos sediciosos do grupo e adotar medidas para a sua supressão. Suas investigações apontavam que Chapman, Calvert, Brewster e Smith foram responsáveis não apenas pela emissão de A Phenix e Mirabilis Annus, mas por uma apologia aos regicidas que condenaram Carlos I à morte em 1649, obras do republicano Henry Vane e outros textos profético-políticos que rejeitavam a soberania do rei e tentavam incitar uma nova sublevação. ${ }^{54}$ Ao conseguir identificar as publicações do grupo e a rede clandestina de produção e dispersão de panfletos elaborada pelos Confederados, L'Estange demonstrava a importância de sua atuação como censor. Assim, a publicação de seus progressos ajudava a evocar e consolidar sua autoridade.

Com os sucessos na detecção e censura de textos controversos, L'Estrange conseguiu fortalecer sua imagem de súdito leal que zelava pela ordem no reinado de Carlos II. Seus serviços foram reconhecidos e gratificados e, pouco depois da publicação de Considerations and Proposals, em agosto, ele foi nomeado como o principal Surveyor of the Press, agora com todos os benefícios e vencimentos que a posição carregava. $\bigcirc$ posto the garantiu poderes para intervir mais profundamente nos negócios do livro, com a possibilidade de examinar casas livreiras e oficinas tipográficas, apreender textos, materiais e sujeitos suspeitos e demandar maior colaboração da Companhia dos Estacionários na supressão de literatura clandestina e sediciosa. ${ }^{55}$

\section{TIPOGRAFIA E MARCAS DE ORALIDADE}

Além do cargo de censor, a ascensão de Roger L'Estrange the rendeu privilégios no mercado livreiro. Ele ficou encarregado da edição e publicação das notícias oficiais do governo, difundidas nos periódicos The Intelligencer e The Newes. ${ }^{56}$ Talvez pela necessidade constante de fazer publicações - fosse de jornais, fosse de panfletos -, o autor-censor instalou seu escritório no cômodo de cima da livraria de Henry Brome, que ficava sob o signo do Canhão (Gun) em Ivy Lane (figura 2). $\bigcirc$ símbolo do livreiro comumente estampou textos escritos pelo censor, ou mesmo obras publicadas por Brome que foram licenciadas por L'Estrange, estabelecendo um referencial à autoridade do escritório do Surveyor of the Press. $\bigcirc$ próprio uso da imagem de uma arma "[...] encimada de uma enorme coroa, representa uma
53. Cf. Keeble (2002).

54. Cf. An Exact Narrative... (1664), Greaves (1986), Bell (1992), Lima (2016).

55. Cf. PRO SP29/78/182.

56. Ibid. 
57. No original: "[...] topped with an enormous crown, represents a powerful Royalist engine [...]" Lynch (2008, p. 18).

58. Signo retirado da folha de rosto de um panfleto anônimo atribuído a Andrew Marvell, licenciado por L'Estrange e publicado por Brome em 1666. A versão digitalizada do texto disponível na Harvard University Library pode ser acessada através da base de dados Early English Books Online (EEBO). Cf. An essay, or... (1666). Imagem produzida pela ProQuest como parte do Early English Books Online e publicada com a permissão da ProQuest. Reproduções sem consentimento são proibidas.

59. Cf. Johns (1998) poderosa máquina Regalista [...]", 57 e, em certa medida, alude à potência com a qual L'Estrange e Brome pretendiam atacar seus oponentes e proteger o reino.

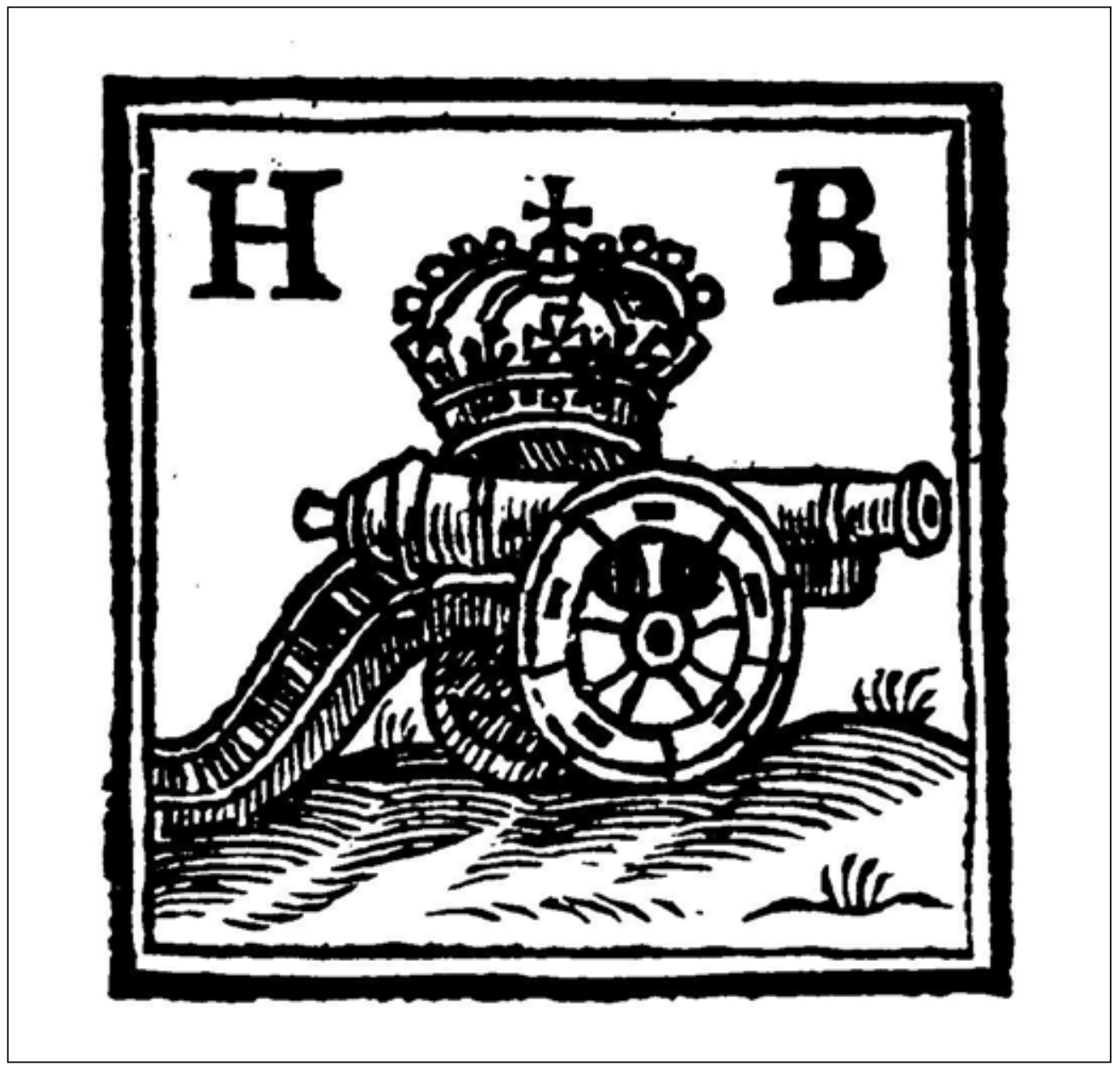

Figura 2 - Signo da livraria de Henry Brome..$^{58}$

escritório sobre a livraria certamente era estratégico para as suas atividades. A partir desse endereço, L'Estrange conseguia ter maior proximidade do dia a dia do mercado de impressos, já que Ivy Lane estava nos arredores da St. Paul's Cathedral, onde grande parte das oficinas tipográficas e casas livreiras se concentravam (figura 3).59 Ao mesmo tempo, era possível participar recorrentemente das atividades de Brome, o que, sem dúvidas, era fundamental para que tivesse controle sobre suas publicações. 


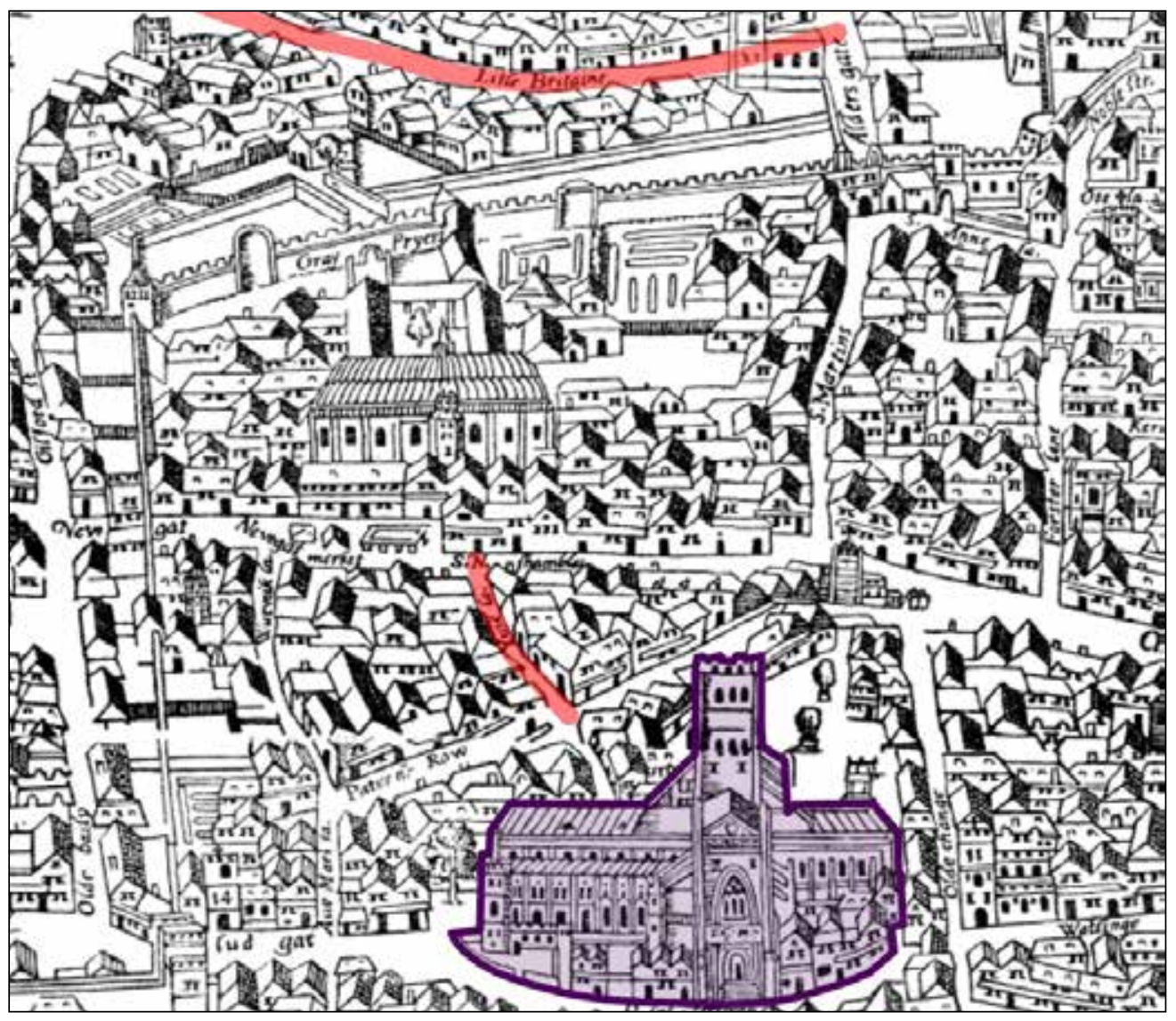

60. O mapa feito por Ralph Agas pode ser consultado a partir do acesso ao website do projeto The Map of Early Modern London. Para saber mais, cf. Jenstad (2018).

61. Cf. Maltzahn (2004), Lynch (2008).

62. Cf. Maltzahn (2004).

Figura 3 - Fragmento do Agas Map de 1561, com destaque para Little Britain (no alto, em vermeIho), Ivy Lane (no centro, em vermelho) e a St. Paul's Cathedral (abaixo, em roxo). ${ }^{.0}$

Em 1666, Brome se mudou para uma propriedade em Little Britain. Embora não dividissem mais o mesmo espaço, o livreiro e o censor continuaram geograficamente próximos, como pode ser visto na figura 3. Além disso, em 1669, a livraria retornou para a região da St. Paul's Cathedral, ladeando, mais uma vez, as imediações do escritório do censor. ${ }^{61}$

As profícuas interações entre Henry Brome e Roger L'Estrange iam além da localização de suas habitações e áreas de trabalho. Os dois parecem ter sido amigos e aliados. Brome apoiou fortemente as publicações de L'Estrange desde, pelo menos, 1659 até sua morte, em 1681. Sua viúva, Joanna Brome, continuou a trabalhar com o autor e censor também até o seu falecimento, em $1684 .{ }^{62}$

Em uma edição de The Observator - jornal publicado por L'Estrange nos anos 1680 -, o autor falou sobre sua longa parceria com Brome. Ele declarava que sua 
63. Na impossibilidade de reproduzir todas as variações tipográficas dos textos de Roger L'Estrange e Henry Brome em nossas transcrições, optamos por utilizar o negrito como substituto das fontes góticas. Tendo em vista que o gótico também era chamado de "black-letter" em inglês justamente por deixar mais traços de tinta preta na página, acreditamos que o negrito poderia exercer um papel semelhante na composição do presente artigo.

64. No original: "[...] first he is Near me, upon any Occasions of Altering, or Correcting. 2ly, He is Carefull of my Work. 3ly, I'le ask no Pragmaticall Fopps leave, what Printer I am to Employ." L'Estrange (1683, fl. 1).

65. No original: "[...] total authorial control over his printer [...]" Birrell (2008, p. 659).

66. Cf. Love (2008).

67. No original: "[...] modulations of the spoken voice" Birrell (2008, p. 659).

68. No original: "[...] clear, easy, natural, slangy, conversational tone of the self-assured aristocrat talking to his social inferiors [...]" Ibid., p. 659.

69. Cf. Love (2008). preferência pelo livreiro se dava por três razões: "[...] primeiro ele está Perto de mim, em qualquer Ocasião de Alteração, ou Correção. 2ª Ele é Cuidadoso com o meu Trabalho. $3^{\circ}$, Eu não peço licença ${ }^{63}$ para nenhum Almofadinha Pragmático, sobre qual Impressor Eu vou Empregar". 64 É interessante notar o destaque dado por L'Estrange à atenção com a qual Brome produzia suas obras, bem como à facilidade em acessar o livreiro para fazer modificações e reparos em seus textos, sugerindo que suas intervenções fossem comuns. Para T.A. Birrell, L'Estrange "[...] tinha total controle autoral sobre seu impressor [...]". ${ }^{65}$ Tal liberdade sobre a composição material de seus textos é atípica para o período, visto que as decisões editoriais tomadas nas casas de impressão e livrarias costumavam depender dos compositores, tipógrafos e livreiros envolvidos diretamente com a produção das obras.

Embora possa-se pensar que a multiplicidade de fontes e símbolos característica dos textos de L'Estrange decorresse unicamente das práticas editoriais de Henry Brome, cabe destacar que nenhuma das demais produções do livreiro se assemelhava ao estilo tipográfico dos impressos do autor-censor. De fato, o mais provável é que L'Estrange participasse ativamente da composição de suas obras. As negociações e associações estabelecidas com Brome eram fundamentais, porque poderiam garantir a execução de composições complexas que, certamente, perturbavam o cotidiano das atividades editoriais da livraria.

A elaboração de impressos que agregavam romanos, itálicos, góticos, sinais gráticos, caixas altas e fontes de tamanhos diversos não era simples. $\bigcirc$ compositor precisaria ajustar a forma múltiplas vezes para que tipos de alturas e larguras diversas ficassem bem acomodados em cada uma das linhas antes da impressão. $\bigcirc$ processo demandaria maior cuidado, atenção e morosidade em comparação a textos que utilizavam uma única fonte. ${ }^{66}$ Nesse sentido, parece evidente que havia um interesse particular em produzir textos com tamanha variação de fontes e recursos gráficos.

O complexo estilo tipográfico de L'Estrange não era arbitrário ou acidental, ele cumpria funções comunicativas. Para T.A. Birrell, o arranjo das páginas de Roger L'Estrange não seguia nenhum padrão ortográfico, mas era elaborado segundo "[...] as modulações da voz falada". ${ }^{67}$ Desde seu uso das maiúsculas e da pontuação até as composições mais complexas, nas quais outras fontes e sinais gráficos eram mobilizados, os textos de L'Estrange reproduziam a oralidade. Em seus jornais, panfletos ou traduções, esses elementos eram empregados em graus e maneiras diversas, de modo a criar o efeito de um "[...] tom claro, fácil, natural, informal, conversacional do aristocrata confiante falando com seus inferiores [...]".68 Mais do que isso, para Harold Love, o estilo tipográfico de L'Estrange poderia evocar suas entonações e até seu sotaque provinciano. ${ }^{69}$ 
Os elementos gráficos, nesse sentido, serviam como dispositivos para guiar a leitura em voz alta. Funcionavam de uma forma tão profunda que "[...] seus textos poderiam quase ser vistos como uma forma gráfica, primitiva de gravação sonora" ${ }^{70}$ De acordo com Love, em alguma medida a potência das obras de L'Estrange poderia estar associada ao seu conhecimento musical, dado que o autor também havia se dedicado ao estudo da viola de gamba desde a sua juventude. Talvez a particular composição de suas obras ecoasse os elementos das partituras musicais, que indicavam ao intérprete como reproduzir cada nota e tom em tempos e ritmos específicos. ${ }^{71}$

A oralidade não pode ser desprezada nas obras de L'Estrange, pois o autor "[...] pensava como ele falava, escrevia como ele falava, imprimia e publicava como ele falava". ${ }^{72}$ A experiência de ler seus textos em voz alta, aplicando as ênfases, desde as mais sutis (grafadas com iniciais maiúsculas e itálicos) às mais dramáticas (em caixas altas ou góticos), transforma o sentido de suas palavras, fazendo com que as ironias, críticas ou provocações tornem-se evidentes, quando poderiam passar despercebidas com uma leitura silenciosa. Nota-se como a pontuação e as maiúsculas do excerto que se segue, extraído de Considerations and Proposals, não seguem as normas da gramática moderna, mas sim as da retórica, representando "[...] a actio da fala como recitação e declamação [... $]^{\prime \prime} .^{73}$ Ou mesmo como os itálicos parecem sugerir a gravidade de cada uma de suas declarações acerca da supressão da literatura controversa:

Diversos Panfletos Traidores e Sediciosos têm sido impressos desde o Ato de Indenização; 74 como, The Speeches of the Late King' Judges; o [Pretenso] Julgamento de Sir Henry Vane, The Prodigies Parte 1 e 2. E Afins. Permita que Estas Pessoas Necessitadas façam saber a Pedido de quem, e às Custas de quem Esses, ou outros Libelos Sediciosos Semelhantes têm sido Impressos, e elas não serão apenas Perdoadas por terem tido uma mão neles Elas mesmas, mas o primeiro Informante deverá sob Prova ou Confissão ser Recomendado ao primeiro Posto para o qual ele for Apto segundo a Nova-Regulação, e o Próximo para o Segundo, e assim sucessivamente: E além disso uma Multa deve ser aplicada aos Chefes da Delinquência, para ser Empregada na Manutenção de tantos Impressores Pobres conforme forem Considerados para Merecer essa Estima, por tal Descoberta. ${ }^{75}$

Na citação em questão, destaca-se não apenas a crítica de L'Estrange aos produtores de panfletos sediciosos, como os Estacionários Confederados responsáveis por todos os títulos mencionados no trecho -, mas a solução apontada pelo autor-censor para acabar com a impressão e circulação de textos ilegais. L'Estrange indicava que muitos agentes do mercado livreiro participavam de negócios escusos devido às necessidades financeiras. Exemplo disso pode ser percebido a partir dos depoimentos de Thomas Creake e George Thresher em
70. No original: "[...] his papers might almost be seen as a primitive, graphic form of sound recording." Ibid., p. 196.

71. Ibid.

72. No original: "[...] thought as he spoke, he wrote as he spoke, he printed and published as he spoke." Birrell (2008, p. 659).

73. Hansen (1998, p. 33).

74. O Ato de Indenização, promulgado em 1660 , foi um perdão régio geral, que escusou todos os crimes cometidos durante o contexto revolucionário, exceto os cometidos por aqueles que estiveram ligados ao regicídio de Carlos I.

75. No original: There have been divers Treasonous and Seditious Pamphlets printed since the Act of Indemnity; as, The Speeches of the Late King' Judges; Sir Henry Vane's [Pretended] Tryal; The Prodigies I Part and 2. And the Like. Let any of These Necessitous Persons, make known at whose Request, and for whose Behoofe These, or the Like Seditious Libells have been Printed, and they shall not only be Pardon'd for having had a hand in it Themselves, but the first Enformer shall upon Proof or Confession be Recommended to the first Vacancy whereof be is Capable in the New-Regulation, and the Next to the Second, and so successively: And moreover Fine shall be set upon the Heads of the Delinquents, to be Employ'd toward the Maintenance of so many of the Indigent Printers as shall be Interpreted to Merit that Regard, by such Discovery." L'Estrange (1663, p. 5). 
76. PRO SP29/28/121, PRO SP29/38/124.

77. Cf. Love (2008).

78. Cf. Chartier (2011).

79. No original: "[...] forms effect sense." McKenzie (2004, p. 18).
1661, nos quais o impressor e o encadernador admitiram suas conexões com os Confederados, mas justificaram suas atividades, explicando que precisavam do dinheiro das encomendas para sobreviver. ${ }^{76}$ Para evitar que alguns estacionários sucumbissem a negócios controversos devido à penúria em que viviam, L'Estrange propunha, em seu Considerations and Proposals, gratificar os sujeitos que denunciassem publicações ilegais, incentivando-os a cooperar com as autoridades.

Nesse excerto, o autor-censor não tinha um tom apenas repressor e acusador, mas conciliador, na medida em que oferecia alternativas aos impressores pobres para que não fossem obrigados a se aliar a empreitadas clandestinas e sediciosas. As modulações vocais sugeridas por meio das maiúsculas iniciais nas palavras mais importantes de seu texto certamente tentavam tornar seu discurso mais persuasivo. Considerando que seus panfletos provavelmente eram lidos em voz alta em pubs e cafés - assim como outros gêneros efêmeros como baladas e jornais ${ }^{77}$-, a tipografia mobilizada aqui era uma estratégia de oratória e retórica que pretendia levar seus ouvintes a perceber sua benevolência. Era como se sugerisse que sua atividade censora protegeria aos estacionários desfavorecidos. Sendo assim, sua fala buscava não apenas constranger infratores, como mobilizar um ambiente de autocensura do mercado livreiro, no qual os agentes eram estimulados a vigiar uns aos outros, e denunciar atividades suspeitas visando às possibilidades de recompensa.

Como podemos perceber a partir desse exemplo, a associação entre tipografia e oralidade desempenhava um papel fundamental nos escritos de L'Estrange, pois articulava-se aos sentidos e aos efeitos que pretendia estimular em seus leitores e/ou ouvintes. A emulação da fala não era exclusividade de seus textos, mas uma prática comum na Época Moderna, quando a leitura silenciosa e solitária ainda não imperava. ${ }^{78}$ Grande parte dos escritos era acessada por meio de leituras em voz alta. Nesse sentido, atentar para a elaboração de marcas de oralidade poderia assegurar uma melhor compreensão da mensagem que se queria propagar. Por essa razão, analisar impressos modernos apenas a partir de seus conteúdos leva a uma perda substancial dos significados. Faz-se necessário examinar outros elementos discursivos expressos na composição material dessas obras. Analisar a materialidade a fim de complexificar as interpretações sobre os textos é, portanto, fundamental. É preciso lembrar, como enunciado por D.F. McKenzie, que "[...] as formas afetam o sentido". ${ }^{79}$ Cada elemento impresso na página, seja um ponto, um recuo, uma palavra em destaque tem implicação para a interpretação da mensagem. 
POLIFONIA E COMPOSIÇÃO DO GÊNERO POLÊMICO

Para além de funcionar como marca de oralidade, a profusão tipográfica de L'Estrange respondia às necessidades do gênero polêmico, do qual ele fazia uso frequente. Vindo do grego polemos, os principais significados de "polêmica" são guerra e batalha. Essa origem militar diz muito sobre o gênero escrito que "[...] é visto como a oposição ao diálogo e à negociação: uma linguagem não comunicativa empregada para destruir um oponente ao invés de convencer um interlocutor" ${ }^{\prime \prime}$

Comumente empregadas em disputas políticas e teológicas, as polêmicas representavam embates entre posicionamentos antagônicos. A partir de estratégias de "[...] conquista e diferenciação [...]", ${ }^{81}$ esses textos utilizavam muitas citações literais. Polemistas incluíam trechos de escritos de seus adversários a fim de que cada um dos argumentos pudesse ser desmontado e refutado. Por essa razão, a impressão das polêmicas recorria a técnicas "[...] para guiar a interpretação do leitor" ${ }^{82}$ A variação de espaçamentos, tamanhos e tipos de fontes bem como o uso de símbolos eram necessários para discriminar as falas impressas na página. "A polifonia tipográfica criada pelo uso de diferentes fontes é uma forma de direcionar a situação de modo a distinguir as vozes autorais e autorizadas daquelas suspeitas". ${ }^{83} \bigcirc$ debate, assim, dependia de uma representação visual elaborada por meio da tipografia.

Como autor-censor, L'Estrange polemizava contra seus opositores recorrentemente. Seus textos, por isso, eram impressos como se fossem verdadeiros campos de batalha. Desde suas folhas de rosto até as erratas, os posfácios e os anúncios que pudessem aparecer ao fim de seus panfletos, as composições pareciam evocar, por um lado, a imagem de L'Estrange como um dedicado servidor da ordem e da moral e, por outro, o perigo dos inimigos sediciosos e as formas de combatê-los em nome da estabilidade política e social. Nesse item de nosso artigo, nos dedicaremos a analisar essas características de seus textos polêmicos.

A começar pelas folhas de rosto, os panfletos de L'Estrange e Brome costumavam ter títulos apelativos gravados em caixa alta, com fontes romanas de tamanho grande, e longos subtítulos que sumarizavam o tema central do texto e/ ou mencionavam diretamente os adversários a serem combatidos. Termos de maior impacto costumavam ter amplo destaque na folha de rosto, funcionando como palavras-chave, que captavam a atenção do público para os principais assuntos da obra, preparando-os ou introduzindo-os à leitura que se seguiria (figura 4).
80. No original: "[...] is seen as the opposite of dialogue and negotiation: uncommunicative language deployed to destroy an opponent rather than convince an interlocutor." Lander (2006, p. 11).

81. No original: "[...] conquest and differentiation [...]". Ibid., p. 11.

82. No original: "[...] to guide the reader's interpretation.” Ibid., p. 30.

83. No original: "[...] to guide the reader's interpretation. [...] The typographical polyphony created by the use of different fonts is one way of addressing the situation by distinguishing authorial and authoritative from suspect voices." Ibid., p. 30. 
84. Cf. L'Estrange (1660b), (1661a), (1661b). Imagem reproduzida com a permissão da Chetham's Library, Manchester (Reino Unido).

85. Cf. Campbell (2009).

86. O imprint trazia as informações a respeito da produção material dos textos impressos na Inglaterra na Época Moderna. Comumente, seguia a seguinte formulação, ao pé da folha de rosto: "Local: impresso por (nome do impressor) para (nome do livreiro-editor), para ser vendido na/no (signo e endereço do livreiro), data". Além de servir como um instrumento de controle, que identificava os responsáveis pelas publicações e estabelecia uma garantia de direitos sobre a produção e circulação da cópia; os imprints eram importantes comercialmente, pois indicavam ao público onde era possível encontrar outras obras semelhantes.

87. No original: "If the Blinde lead the Blinde, Both shall fall into the Ditch." L'Estrange (1660c, fl. 1).

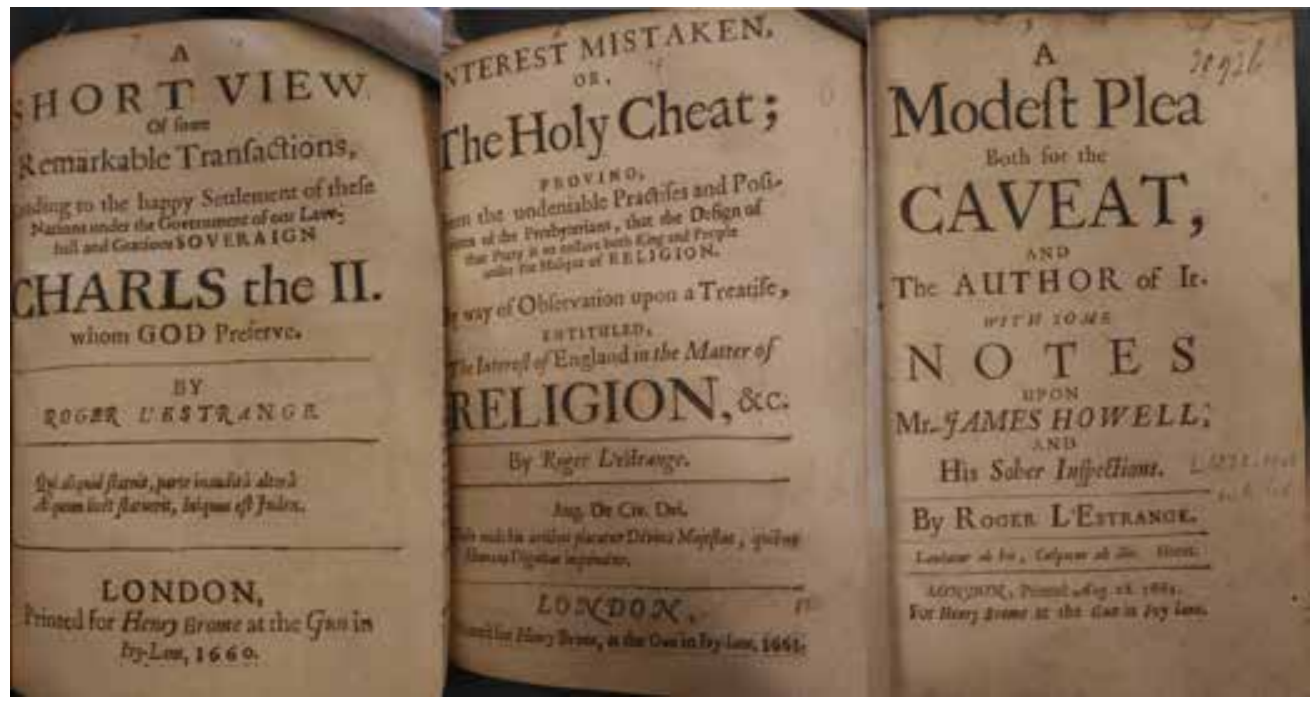

Figura 4 - Exemplos de folhas de rosto publicadas por L'Estrange e Brome. ${ }^{84}$

Com maior ou menor destaque, o nome de L'Estrange costumava aparecer. Sendo um prolífico panfletista, jornalista e tradutor, suas obras costumavam adquirir certo sucesso editorial. Nesse sentido, a menção ao autor poderia ser uma boa estratégia comercial. Seu nome, contudo, poderia ser omitido, caso o assunto ou o debate travado com outra pessoa pudesse chamar mais a atenção do que a própria identidade de L'Estrange. Esse parece ter sido o caso de No Blinde Guides, publicado por L'Estrange e Brome em 20 de abril de 1660, pouco depois de Carlos II assinar a Declaração de Breda. Interessados em responder aos textos sediciosos recentemente lançados pelo poeta republicano John Milton, L'Estrange e Brome parecem ter composto uma folha de rosto que em si mesma já representava um ataque ao adversário (figura 5).

Otítulo No Blinde Guides (em tradução livre: "Sem Guias Cegos") fazia clara referência e provocação à deficiência visual do poeta, que perdera a visão em 1652. ${ }^{85}$ A ofensa foi continuada e, de certa forma, legitimada pelo uso de uma citação bíblica pouco antes do imprint. ${ }^{86}$ Retirada de Mateus 15. 14, a frase dizia: "Se o Cego guiar o Cego, Ambos podem cair na Vala". ${ }^{87}$ Ao mesmo tempo em que satirizava John Milton, o título de L'Estrange já introduzia a tônica principal do restante de seu texto: o poeta não era adequado à árdua tarefa de apontar a melhor direção para o povo da Inglaterra. Sua cegueira não era apenas física, mas moral e política, visto que Milton era um apoiador da república, e, portanto, uma ameaça à ordem que começava a ser restabelecida por Carlos II. A necessidade de combater seus posicionamentos sediciosos talvez seja a razão pela 
qual L'Estrange e Brome mencionaram Milton duas vezes na folha de rosto. O nome do poeta aparece na quinta linha, em caixa alta e itálico e, depois, é aludido na décima primeira, com a expressão "Endereçado ao Autor"88 (figura 5).

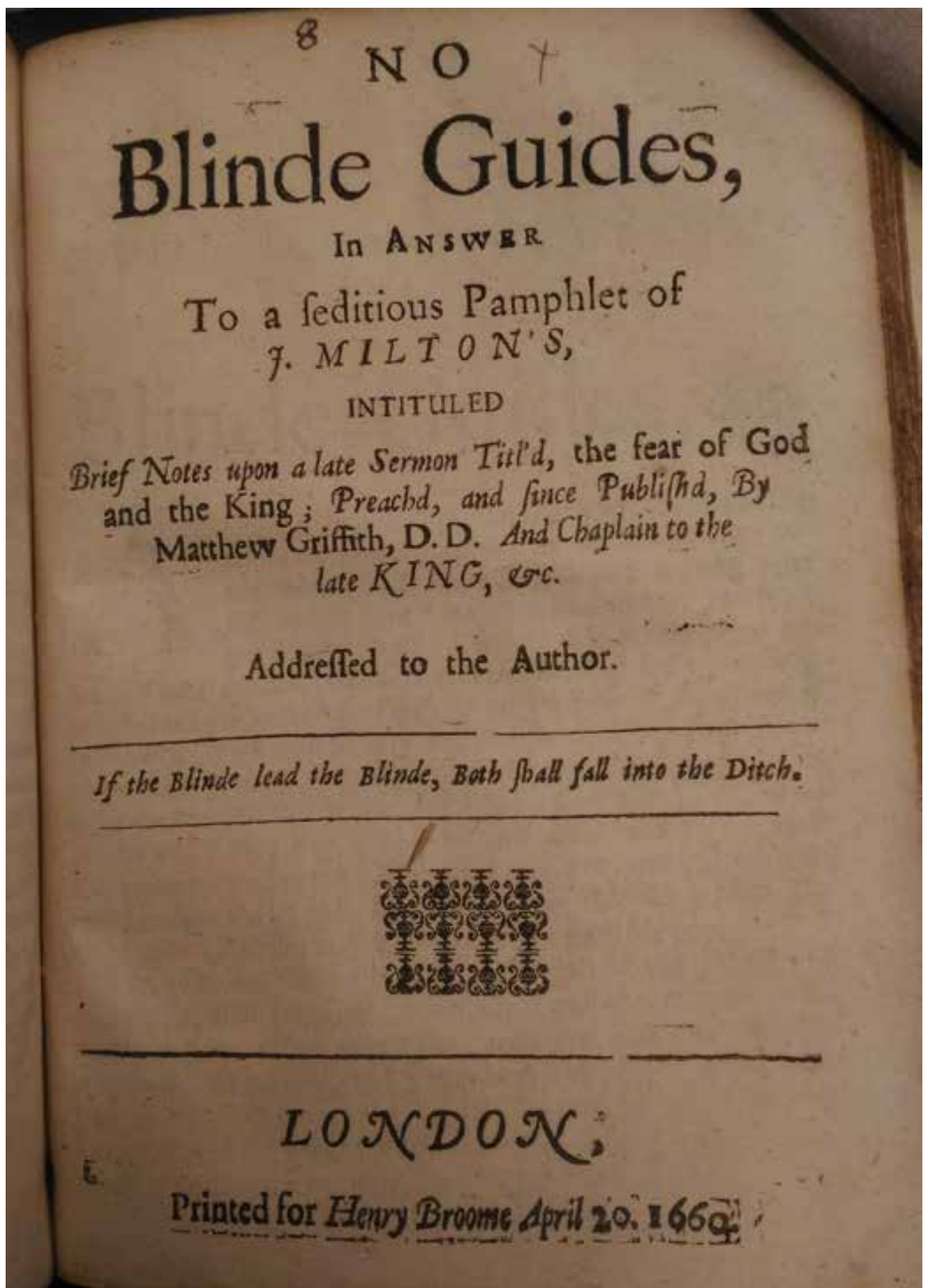

88. No original: "Addressed to the Author." Ibid., fl. 1.

89. Cf. L'Estrange (1660c). Imagem reproduzida com a permissão da Chetham's Library, Manchester (Reino Unido).
Figura 5 - Folha de rosto de No Blinde Guides (1 660). ${ }^{89}$ 
90. Cf. Milton (1660a).

91. Cf. Griffith (1660).

92. No original: "[...] by our fundamental law, the King is the highest power [...]". Milton (1660b, p. 8).

93. No original: "[...] no law can be fundamental, but that which is grounded on the light of nature of right reason, commonly call'd moral law: which no form of Government was ever counted; but arbitrarie, and at all times in the choice of every free people, or thir representers. [...] In this land not only the late King as his posteritie, but kingship it self hath bin abrogated by a law; which involves with as good reason the posteritie of a King forfeited to the people, as the Law heretofore of Treason against the King, attainted the children with the father." Ibid., p. 8.
Em No Blinde Guides, L'Estrange respondia a dois recentes panfletos antirregalistas do poeta. $O$ primeiro era The readie \& easie way to establish a free Commonwealth, publicado pelo impressor Thomas Newcomb e pelo livreiro Livewell Chapman. Em seu texto, Milton fazia um apelo para que o povo inglês evitasse a tirania de uma nova monarquia que, segundo o autor, apenas levaria a uma repetição dos sofrimentos de outrora. Na altura em que escrevia, Milton via a possibilidade de aproveitar a breve república que se seguiu à abdicação de Richard Cromwell para a consolidação de uma Commonwealth duradoura, livre e justa. Para ele, essa era a forma mais perfeita e estável de governo, visto que não dependia das vontades e perspectivas de uma única pessoa. Num regime monárquico, se estivessem nas mãos de um bom governante, as pessoas poderiam gozar de suas liberdades, mas caso o soberano seguinte fosse ruim, não haveria escapatória. Alternativamente, numa república, qualquer tirano poderia ser removido sem prejúżo para o povo. Da mesma maneira, com eleições de um conselho, evitar-se-iam os riscos de novas opressões comandadas por um governante injusto. ${ }^{90}$

A segunda publicação, mencionada na folha de rosto de No Blinde Guides, era Brief notes upon a late sermon, titt'd, The fear of God and the King. O texto criticava um sermão de Matthew Griffith, ex-capelão de Carlos I. Em sua fala (posteriormente impressa), Griffith defendia que a única solução para as aflições vividas pela Inglaterra era a retomada do regime monárquico. ${ }^{91} \mathrm{Em}$ seu panfleto, Milton refutara trechos do sermão, sugerindo que não havia fundamentação histórica, bíblica ou jurídica para apoiar a restauração de Carlos II. De acordo com Milton, era incorreto afirmar (como fazia Griffith) que "[...] pela nossa lei fundamental, o Rei é o soberano [...]"92 porque

[...] nenhuma lei pode ser fundamental, posto que se baseia na luz da natureza da reta razão, comumente chamada de lei moral: na qual nenhuma forma de Governo jamais foi imputada; mas arbitrada, e em todas as vezes a partir da escolha das pessoas livres, ou de seus representantes [...] Nessa terra não apenas o falecido Rei e seus descendentes, mas a própria monarquia foi abolida por lei; o que implica pela reta razão que a descendência de um Rei foi confiscada para o povo, assim como a Lei de Traição contra o Rei, que desonra os filhos a partir do pai. ${ }^{93}$

L'Estrange discordava em absoluto das palavras de Milton e, por isso, se colocou como um defensor da soberania do monarca. Nas primeiras páginas de No Blinde Guides, o autor redigiu uma epístola na qual tecia a imagem do poeta como um traidor. Ele perguntava em tom inquisitivo: "Não foi Você, que escreveu uma Justificativa do Assassinato do Rei [...] e o tornou bom também, Então? Aquele assassinato foi uma Ação meritória, se comparado à sua maldade 
superior". ${ }^{94}$ Para além de suas ásperas palavras, observa-se o uso dos itálicos que potencializavam o discurso de L'Estrange. $\bigcirc$ primeiro destaque aparece na palavra "Você", as demais ocorrências, nesse sentido, parecem se ligar a esse sujeito. Os itálicos seguintes estão em "Assassinato do Rei", "bom" e na última sentença acusatória de L'Estrange. Saltando aos olhos do leitor, as ênfases parecem sugerir uma associação entre Milton e a morte do monarca que, perniciosamente, fora legitimada e enaltecida pelo poeta. Mas logo em seguida, a acusação mais grave foi inteiramente grafada com itálicos, apontando que, pior que o assassinato em si, era a posição de Milton em defendê-lo.

As palavras de L'Estrange pareciam não dar espaço a um debate. Sua proposta não era estabelecer comunicação com o outro, ou mesmo tentar convencer o público de seu posicionamento. Mais do que isso, a pena ágil e furiosa de L'Estrange visava arrasar seu oponente, tomando como ponto de partida a caracterização do poeta como um criminoso vil e cego, que enganava aqueles que o seguiam.

Para que a aniquilação de seu adversário fosse efetiva, L'Estrange incluía em suas respostas a Milton uma série de citações para serem fortemente rebatidas. Dessa maneira, o autor poderia demonstrar exatamente todos os pontos controversos das falas do poeta. Como pode ser visto na reprodução da figura 6, L'Estrange expôs um longo parágrafo de Brief notes no qual Milton afirmava que a guerra contra Carlos I fora justa e, por conseguinte, a extirpação do poder monárquico também. Esse excerto de Milton foi grafado em fontes romanas de tamanho menor do que as utilizadas nas demais passagens, talvez em uma tentativa de reduzir a importância da fala de Milton face a de L'Estrange. Além disso, as palavras do poeta estão espacialmente afastadas das de L'Estrange, configurando um bloco de texto separado que distingue a voz do autor de No Blinde Guides daquela de seu oponente.

Nos dois parágrafos seguintes, L'Estrange retomou a palavra para dizer que Milton estava equivocado, pois o regime monárquico precisava ser reinstituído para que houvesse estabilidade no governo da Inglaterra:

Se a Monarquia nunca fosse estabelecida, o que seria então eu the rogo? não teríamos Governo algum?

Nem poderia ser, como você diz: Então agora quanto à sua pronta e fácil maneira de ESTABELECER uma COMMONWEALTH LIVRE, o que será do SEU CONSELHO PERMANENTE? Se nenhuma forma certa de Governo pode ter vínculo para a posterioridade (como você afirma) Então é possível que a qualquer momento o Povo se Reúna, e Tumultue, sob as cores de uma nova Escolha. ${ }^{95}$
94. No original: "Was it not You, that scribled a Justification of the Murther of the King, [...] and made it good too, Thus? That murther was an Action meritorious, compared with your superior wickedness." L'Estrange (1660c, p. 1).

95. No original: "If Kingship was never established, what was I beseech you? had we no Government?/Nor could it be, you say: Alas then for your ready, and easie way to ESTABLISH a FREE COMMONWEALTH, what will become then of YOUR STANDING COUNCIL? If no certain form of Government can bind our posterity (as you affirm) Then is it free at any time for the People to Assemble, and Tumult, under the colour of a new Choyce." Ibid., p. 11. 
96. Ibid. Imagem reproduzida com a permissão da Chetham's Library, Manchester (Reino Unido).
Lom of the Members. It is one thing, a Law chat's made in the Abfence of many of the Members, thit might have been Prefent, if they would; (and are poffibly fined for non-atsendawe ) and another thing; th: Vote of a tenth Part of That Body, which it felf entire, is but the third Part of the Legißative Power: This Kemmant too by force of Armes violently fecluding the Rief.

B.t you have no Confcience with you. King hip L Lalifhed vill not do your work it fecms.

You fuppofe ic never was effat If h'd by any certain Law in this Land, nor poffibly could be: for how could our forefathers biad us to any certain form of Government, more then we can bind our golteritie? If a peoplebe put to war with their King for his milgovernment, and overcome bim, the power is then undouberdly in cheir own hands how they will be gov rn'd. The war was granted juf by the King himfelf at the beginning of his laft Treatic; and ftill maintained to be fo by this laft this next en'uing, That none fications prefcrib'd to the Members of gainft the Parliament fince 160 , If if be tected, who have born arms aallo jult by the Law of Nations Ane war weie juf, the Conqueft was all righte ceaied to be the King, efpecially foro wat che chicf enemie, in verdit of war ; and royalcic with all hy $r$ fer captivitic, by the deciding mins in the vittozs power, together with the choict pretentions, yee re-
verument.

IF king fo $\rho$ was never eftablified, what ip as I befeech you $>$ had Nor could is be

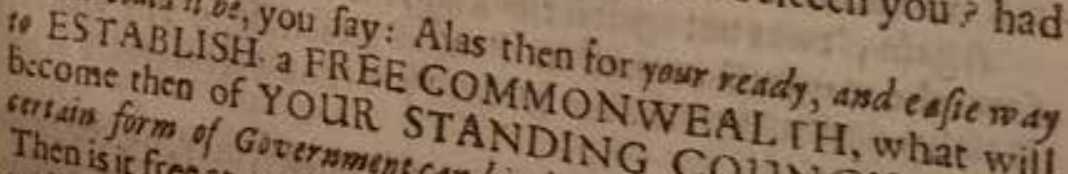
Then is it free at avernmens can bind under the colour of a new forthe Pcople to Aferit, (as you affirm)

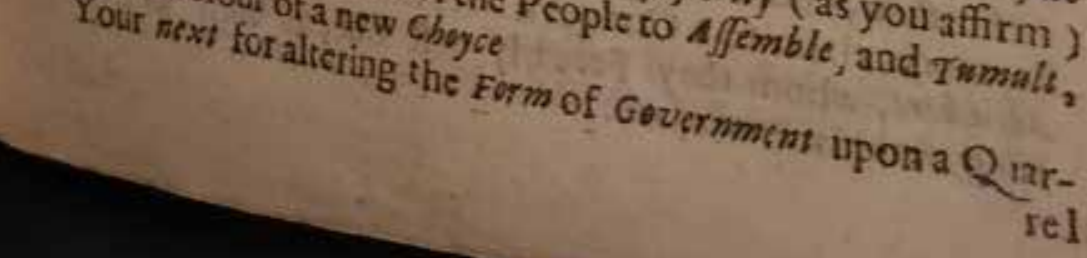

Figura 6 - Trecho de No Blinde Guides com destaque para a citação de Milton e a crítica de L'Estrange. ${ }^{96}$ 
Segundo L'Estrange, uma república tal como a apoiada por Milton seria instável o suficiente para suscitar novas rebeliões e alternâncias de governo, como ocorrera nas décadas anteriores. A monarquia era a melhor alternativa para a manutenção da ordem e, portanto, precisava ser defendida. Defesa essa que contava não apenas com as palavras de L'Estrange, mas com a visualidade da tipografia formulada pelo autor e seu livreiro-editor. Nesse trecho, os itálicos são utilizados de duas maneiras. Da primeira até a sexta linha, o recurso destaca as palavras oriundas do texto de Milton. Nas duas últimas linhas, o itálico refere-se à fala do próprio L'Estrange, enfatizando os riscos contidos em possíveis reuniões, tumultos e escolhas do povo. As caixas altas, por sua vez, parecem conferir uma ênfase ainda mais dramática a termos mobilizados por Milton em The readie \& easie vvay e Brief Notes, numa tentativa de escancarar o perigo do posicionamento apoiado pelo poeta republicano.

Embora os mesmos recursos, como os itálicos, pudessem ser mobilizados em vozes diferentes, as estratégias tipográficas de L'Estrange e Brome certamente não confundiam os leitores seiscentistas. Os elementos gráficos normalmente eram aliados a passagens metadiscursivas que esclareciam quem poderia ser o emissor de cada mensagem, distinguindo quando os itálicos funcionavam como ênfases ou citações. Por exemplo, no excerto anterior, L'Estrange escreveu "como você diz" e "(como você afirma)" logo após trechos extraídos de Milton. Com a interlocução entre as formas e os conteúdos, o sentido da mensagem de L'Estrange tornava-se mais claro.

A articulação desses recursos tipográficos e textuais em polêmicas impressas não era incomum. Ainda que L'Estrange tivesse um estilo particular para sua época, suas composições podem ser comparadas a outros textos de meados do século XVII. Em alguma medida, suas páginas se assemelham às do pentamonarquista John Rogers (figura 7), do advogado William Prynne (figura 8), ou do ministro religioso Thomas Edwards (figura 9), três outros prolíficos polemistas.

John Rogers fora um pastor pentamonarquista que acreditava que a Segunda Vinda de Cristo, prevista no Livro de Daniel, conformaria um governo civil na Terra. Os mil anos de felicidade eram, para ele, concretos e poderiam ser acelerados se o povo inglês aderisse a reformas políticas, jurídicas, sociais e econômicas que estivessem de acordo com as Escrituras. Com o fim da Revolução Inglesa e a maior radicalização do movimento dos Homens da Quinta Monarquia, Rogers passou a defender uma república teocrática e a participar amplamente dos debates a respeito dos modelos políiticos que poderiam ser adotados pela Inglaterra. Grande parte dos seus textos buscava responder às ideias defendidas pelo republicano James Harrington e pelo monarquista William Prynne. Seu Diapoliteia (figura 7) congregava inúmeras citações de seus adversários e, por conseguinte, contava 
97. Cf. Santos Junior (2014), Greaves (2008).

98. Rogers (1659). (C) British Library Board. Imagem produzida pela ProQuest como parte do Early English Books Online e publicada com a permissão da ProQuest. Reproduções sem consentimento são proibidas

99. Cf. Santos Junior (2014), Lamont (2011). com itálicos, góticos e notas marginais provavelmente elaboradas em conjunto com seu livreiro-editor e colega pentamonarquista, Livewell Chapman. ${ }^{97}$

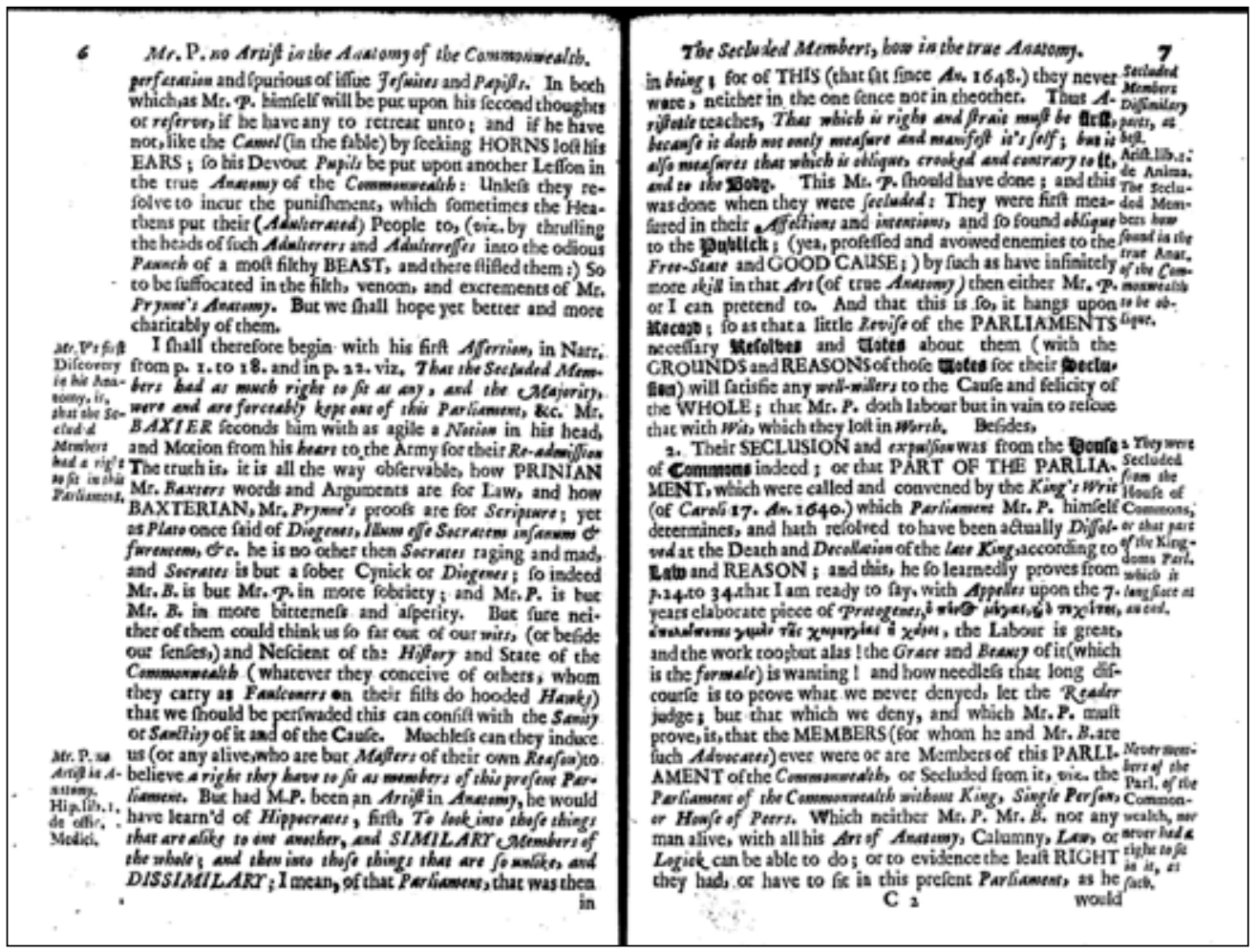

Figura 7 - Trecho de Diapoliteia (1659), de John Rogers.98

William Prynne era uma figura mais emblemática, pois havia mudado de posição diversas vezes. Antes da Revolução Inglesa, já havia entrado em conflito com a monarquia. Em seu Histriomastix (1632), acusara as mulheres que participavam de peças teatrais de serem prostitutas. Sua afirmação fora entendida como uma crítica direta à rainha Henriqueta Maria, que atuara em The Shepherd's Paradise. Por essa razão, foi julgado e punido por seu ato sedicioso. Ao longo do contexto revolucionário, envolveu-se em diversas controvérsias, oscilando entre apoios ao Parlamento e, depois da execução de Carlos I, ao rei. Em suas disputas com John Rogers e defensores da Commonwealth, Prynne também fazia uso de múltiplos excertos de seus adversários. Em razão disso, seus textos polêmicos comumente eram marcados com itálicos, góticos e notas marginais (figura 8). ${ }^{99}$ 


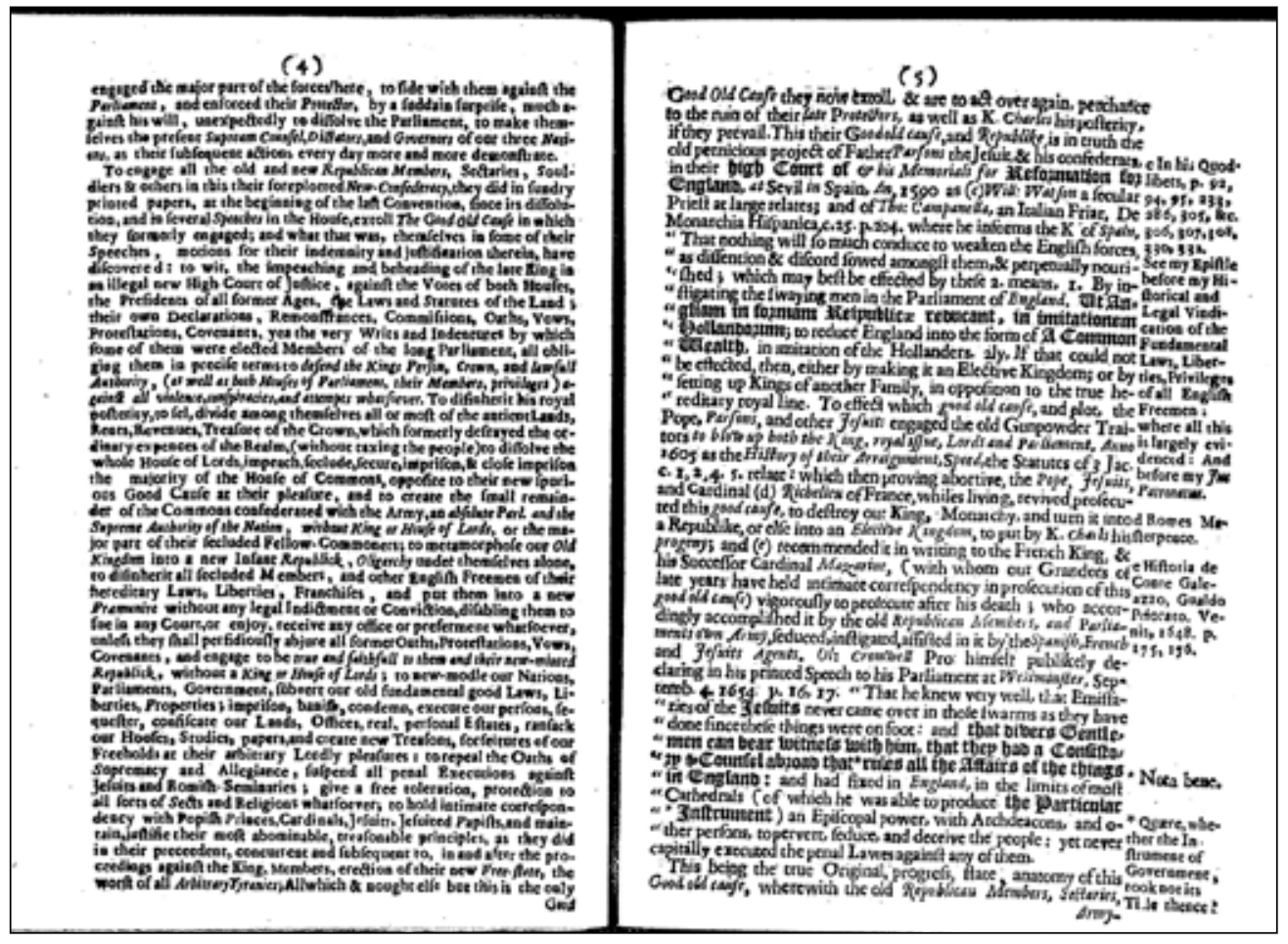

Figura 8 - Trecho de The re-publicans and others spurious good old cause, briefly and truly anatomized (1659), de William Prynne. ${ }^{100}$

Já Thomas Edwards tivera como grande trabalho uma compilação dos erros que julgava serem as razões para a "doença" vivida pela Inglaterra no início das Guerras Civis. Para ele, eram os sectários religiosos que gangrenavam a política e a sociedade, gerando tamanha instabilidade. Em seus três volumes de Gangraena (publicados ao longo de 1646), os crimes e heresias dos sediciosos não eram apenas mencionados, mas exemplificados por meio de diversos trechos de seus posicionamentos e crenças. Assim, sua obra era caracterizada pela intertextualidade e o recurso a múltiplas vozes. Ainda que seus impressores, Thomas Ratcliffe e Edward Mottershed, e seu livreiro, Ralph Smith, não tivessem utilizado uma profusão de fontes e símbolos diversos, seu Gangraena também contava com muitos itálicos e notas marginais para distinguir as citações que mobilizava (figura 9). ${ }^{101}$
100. Prynne (1659). (C) British Library Board. Imagem produzida pela ProQuest como parte do Early English Books Online e publicada com a permissão da ProQuest. Reproduções sem consentimento são proibidas.

101. Cf. Nogueira (2017), Baker (2004). 
102. Edwards (1646). (C) British Library Board. Imagem produzida pela ProQuest como parte do Early English Books Online e publicada com a permissão da ProQuest. Reproduções sem consentimento são proibidas.

103. Cf. Lander (2006)

104. Cf. Love (2008)

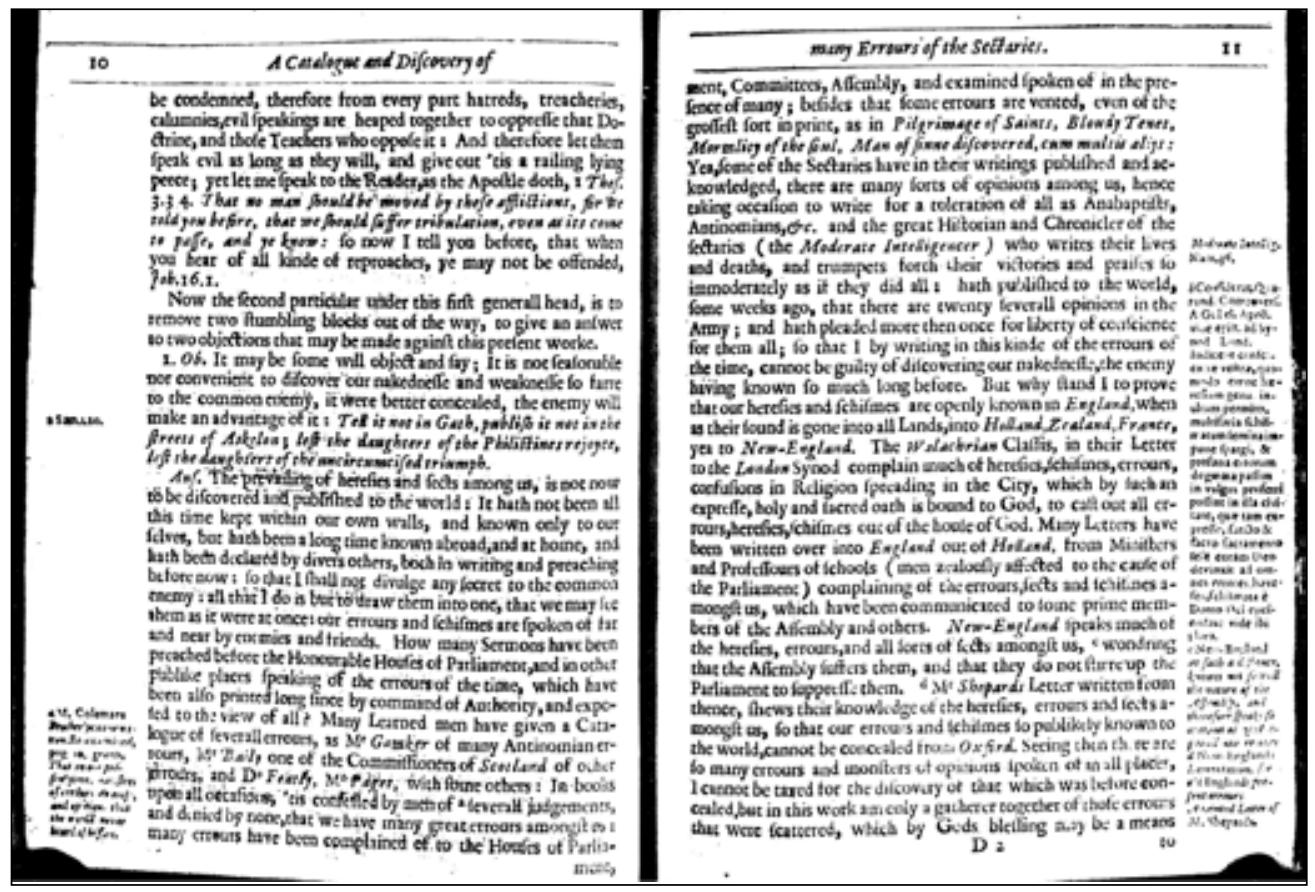

Figura 9 - Trecho de Gangraena, de Thomas Edwards (1646). ${ }^{102}$

Embora estivessem de lados muito diferentes no espectro político e religioso, L'Estrange, Rogers, Prynne e Edwards tinham em comum a voracidade dos debates públicos dos quais participavam e o recurso ao gênero polêmico. Suas obras são comparáveis, mas há que se considerar, entretanto, que nem todos os títulos de Rogers, Prynne e Edwards carregavam essa mesma composição tipográfica. Ela parece configurar uma das possibilidades de impressão de seus escritos, utilizada particularmente nas publicações polêmicas, nas quais a necessidade de distinguir vozes diversas era imprescindível para a correta compreensão da mensagem, ${ }^{103}$ mas não caracteriza uma prática tão recorrente na produção de suas obras.

No caso de Roger L'Estrange, há maior constância no recurso a esse estilo tipográfico. A totalidade de seus textos produzidos por Henry Brome parece manter a complexidade gráfica referida até aqui, o que nos leva a acreditar que a elaboração das páginas de L'Estrange estava alinhada às características das polêmicas impressas, mas não se resumia a elas. ${ }^{104}$ Cabe, então, compreender quais outros interesses e implicações poderiam estar envolvidos na composição de suas publicações. 
Nos panfletos de Roger L'Estrange e Henry Brome, a tipografia exercia funções comunicativas complexas que a todo momento evocavam e combinavam escrita/ leitura, oralidade e visualidade. De fato, o apelo visual era tão importante para a obra de L'Estrange que em um de seus textos de 1661, Interest Mistaken, or, The Holy Cheat, ele não tratou apenas de responder a The Interest of England In the Matter of Religion, de John Corbet, como também atacou a folha de rosto da obra. Para isso, o autor se preocupou em reproduzi-la no meio de seu texto, mas não sem antes enunciar que já ali, "[...] para mim, ele tropeça no limiar". ${ }^{105}$ Como pode ser visto por meio da comparação representada na figura 10, L'Estrange e Brome compuseram uma cópia da folha de rosto de The Interest of England, imitando, ainda que com algumas alterações, a disposição e os destaques das palavras da edição de Corbet.

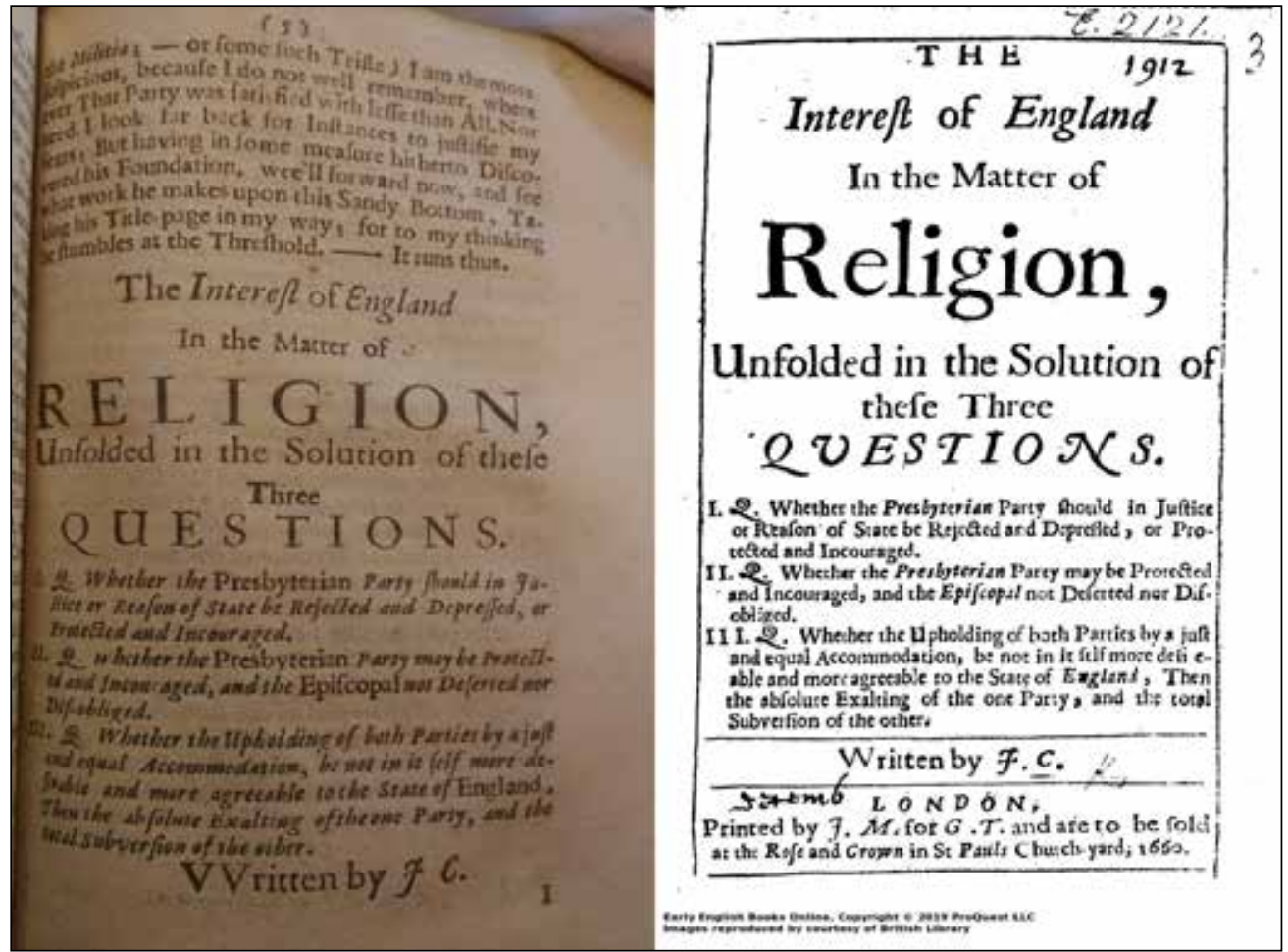

Figura 10 - À esquerda, reprodução da folha de rosto de The Interest of England em Interest Mistaken (1661); à direita, folha de rosto da publicação de Corbet de 1660.106

A reprodução da folha de rosto parece servir de alerta para que o público não fosse enganado pelo texto vil. Embora parecesse tratar de assuntos
105. No original: "[...] to my thinking he stumbles at the Threshold." L'Estrange (1661a, p. 5).

106. Cf. L'Estrange (1661a). Imagem reproduzida com a permissão da Chetham's Library, Manchester (Reino Unido). Corbet (1660). (C) British Library Board. Imagem produzida pela ProQuest como parte do Early English Books Online e publicada com a permissão da ProQuest. Reproduções sem consentimento são proibidas. 
107. Cf. Corbet (1660).

108. No original: "[...] Obedience to the Establish'd Law; not the Encouraging of froward Humours, by an Audacious, and mis-govern'd Zeal, under pretext of Conscience to Affront it." L'Estrange (1661a, p.6).

109. No original: "I do acknowledge and Declare that the Warre undertaken by Both houses of Parliament in their Defence against the forces raised in the Name of the Late King, was Just and Lawfull; and that Magistracy and Ministery, are the Ordinances of God.” L'Estrange (1661a, p. 12).

110. No original: "[...] God forbid, That Declaration charging the Guilt, and Blood of the late War upon the King, should stand upon Record to future Generations. Whoever affirms That War was lawful, does beyond Question meditate Another, not to say more than needs, It Blasts the Memory of the Late king, and upon the king that now is, it reflects many Mischiefs: subjecting both his Dignity, and Person to His Fathers Hazzards. It administers Argument for a new War; and shakes the very Foundation of Royalty." Ibid., p. 12 de interesse público e teológico, como indicado em seu título e subtítulo, L'Estrange apontava que The Interest of England era enganoso porque defendia causas sediciosas. Presbiterianos como Corbet acreditavam que o poder do rei deveria ser limitado, pois o monarca - assim como todas as pessoas - também estava submetido a Deus e às Suas leis. ${ }^{107}$ Para L'Estrange, esse jamais seria um interesse da Inglaterra, pois o que importava era a "[...] Obediência à Lei Estabelecida; não o Encorajamento de Humores impertinentes de um Audacioso, e malgovernado Zelo, sob o pretexto da Consciência para Afrontá-la". ${ }^{108}$

Para L'Estrange, o texto de Corbet não passava de uma coletânea de ofensas propagadas por um fanático, as quais precisavam ser combatidas. Dessa forma, as 148 páginas de seu Interest Mistaken são dedicadas a destruir cada um dos argumentos de seu oponente. Ao retratar trechos particularmente sediciosos, L'Estrange e Brome reforçavam o perigo das palavras de Corbet por meio do uso de tipos góticos. Como pode ser visto na figura 11, uma citação de The Interest of England foi destacada com grandes letras góticas que saltam aos olhos do leitor.

O trecho em questão dizia: "Eu reconheço e Declaro que a Guerra feita por Ambas as Casas do Parlamento em sua defesa contra as forças levantadas em Nome do Finado Rei, foi Justa e Legal; e que a Magistratura e o Ministério, são as Ordenanças de Deus". ${ }^{109}$ Mais abaixo, L'Estrange denunciava a traição impregnada nas palavras de Corbet:

[...] Deus impeça, que Esta Declaração atribuindo a Culpa, e o Sangue da última Guerra ao Rei, permaneça nos Registros para as futuras Gerações. Quem quer que afirme Que a Guerra foi legal, sem Dúvida cogita Outra, para não dizer mais do que é preciso, Isso Destrói a Memória do Finado rei, e sobre o rei de agora, reflete muitos Prejuízos: subjugando tanto a sua Dignidade, quanto a sua Pessoa aos Infortúnios de Seu Pai. Isso conduz Argumento para uma nova Guerra; e abala a própria Fundação da Realeza. ${ }^{110}$

Brome e L'Estrange parecem ter sido cuidadosos o suficiente para diferenciar claramente as duas posições contrastantes, não permitindo que o leitor confundisse as afirmações leais e zelosas de L'Estrange com as sedições proferidas por seu adversário. Mais do que isso, a escolha do gótico em contraste com o romano tem outras implicações. A ênfase exagerada, que destoava fortemente do restante da composição da página, direcionava o olhar do público, frisando a gravidade daquele excerto. Com tamanho destaque, L'Estrange e Brome demonstravam os absurdos proferidos por presbiterianos como Corbet, os quais precisavam ser suprimidos devido aos riscos que ofereciam ao governo e à sociedade. 
7) $\left(x_{2}\right)$

3) Do actinonoleoge and that the 329 atre undertaken Dellate

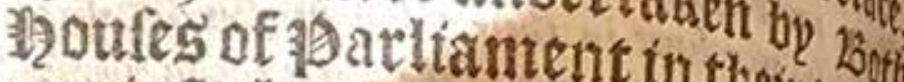
andint the forces raif on their defines

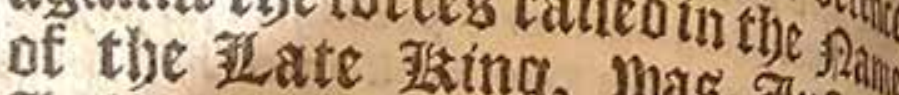
ULabuil; ano that Las Jute and Biniftery, are the Dagitracy an ธDD.

Th: Second, was in the exclufion of the Rop Rarty from the next Choice, as followeth Refolved that all andevery Perfon who have woild or voluntarily atded, abbetted, or affisted, in ur wio againft she Parliament (fince the firf day of loury 1641.) his or their Sons, unleffe be or they len fat Minifyfed t beir good affe etrions to this Parlisem, fat be uncapable to be elected vo firve as Membersitionat Parliament

Now how a Choice thus limited in the Hoole and Principled in the Field, fhould Necelforith let is right, does not to me appear? Perhaps it ws th moft the Time would bear : but God fobbi, this Declaration charging the Guilt, and Blood of the th war upon tbe King, fhould fand upon Recordroler Generations. Whoever affirms That War wat it: ful, does beyond Queftion meditate Anothers ofl fay more than needs, It Blafts the Memory d Late King, and upon the King that now is, it "1 many Milchiets : I W Oing both his Dignith Perfon to His Fathers Hazzards both his Dignity, gument for a new War, and fords. It adminifts

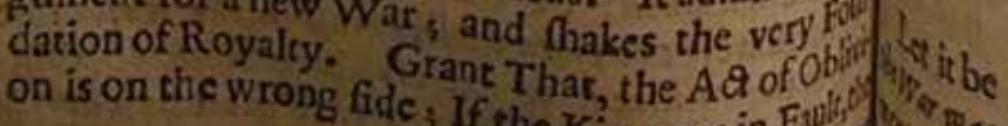
Presbyt
111. Ibid. Imagem reproduzida com a permissão da Chetham's Library, Manchester (Reino Unido).

Figura 11 - Fragmento de Interest Mistaken, or The Holy Cheat (1661), página 12.111 
112. Cf. Watt (1993).

113. Cf. Lesser (2006).

114. Cf. Thomas (1986)

115. No original: "[...] a $s e$ miotic explanation, seeing black letter as a signifier carrying meaning [...]" Lesser (2006, p. 104).

116. Ibid.
Além disso, é interessante mencionar que, para pesquisadores como Tessa Watt, o emprego do gótico ou black letter era comum em textos oriundos de uma imprensa barata e popular, como baladas, folhas volantes e chapbooks. ${ }^{112}$ Sua ocorrência no panfleto de L'Estrange e Brome poderia, por conseguinte, ser uma tentativa deliberada de atacar a autoridade e erudição de Corbet, associando-o a uma literatura baixa e de pouco prestígio. Não obstante, como demonstrado por Zachary Lesser, ainda não há consenso na comunidade acadêmica a respeito dos significados do uso do gótico em textos ingleses a partir do século XVII. ${ }^{113}$ Os tipos romanos tornaram-se extremamente usuais nos seiscentos, mas os góticos continuavam a ser mobilizados em alguns gêneros, fossem aqueles tidos como populares, fossem aqueles mais elevados, como livros de direito, Bíblias e decretos oficiais. $\bigcirc$ gótico também era comumente utilizado em gramáticas, catecismos e abecedários, o que - levou a ser descrito por muitos pesquisadores como uma fonte mais compreensível e legível para leitores pouco instruídos. ${ }^{114}$ Nessa perspectiva, a black letter em Interest Mistaken poderia ser uma forma de garantir a rápida e plena compreensão da citação de Corbet. A associação com uma literatura popular, consequentemente, nem sempre é profícua, pois pode ocultar outras intenções. Para Lesser, é fundamental compreender a black letter a partir de "[...] uma explanação semiótica, percebendo o gótico como um significante que carrega sentido [... $]^{\prime \prime}$.115 $^{11}$

Nas obras de L'Estrange e Brome não parece existir um padrão claro para o uso do gótico. As funções da black letter variavam de acordo com os conteúdos articulados pelo autor em cada um de seus panfletos. Em Truth and Loyalty Vindicated (1662), por exemplo, o censor utilizara góticos em todas as citações de declarações régias (figura 12). Os discursos do rei eram edificados com a black letter que, nesse caso, remetia a uma autoridade que deveria ser reconhecida e respeitada. ${ }^{116}$

Nesse panfleto, L'Estrange respondia ao ministro independentista, Edward Bagshaw que não havia se conformado à lgreja da Inglaterra mesmo depois da obrigatoriedade imposta pelo Ato de Uniformidade de 1662. Em seu The Great Question Concerning Things Indifferent in Religious Worship, publicado em três partes entre 1660 e 1662, Bagshaw se contrapunha ao exercício de diversos ritos religiosos, acusando-os de serem práticas papistas. Tendo em vista que a posição de Bagshaw vinha na contramão das recentes determinações régias a respeito do anglicanismo, L'Estrange julgava necessário denunciá-las e combatêlas, pois ameaçavam a unidade e estabilidade da religião na Inglaterra. Sua estratégia, dessa forma, era contrastar Bagshaw com Carlos II. No início da página 10 (ilustrada na figura 12), L'Estrange justapôs ambas as asserções: 
Nós estamos muito felizes em descobrir, (diz sua Majestade) que todos com quem conferenciamos, aprovam em seu Julgamento que uma Liturgia, ou Forma de Adoração Pública seja Lícita; o que em Nosso Julgamento, para a preservação da Unidade, e Uniformidade, consideramos ser muito Necessário. Agora ouça o Sr. Bagshaw em oposição a Isso.

Curvar-se ao Nome de Deus, a Cruz no Batismo, Figuras nas Igrejas, Súplicas na Pregação, Ajoelhar no Sacramento, Formas de Adoração, e afins, - Eu considero absolutamente ilegal para qualquer Magistrado Cristão impor o uso deles. ${ }^{17}$

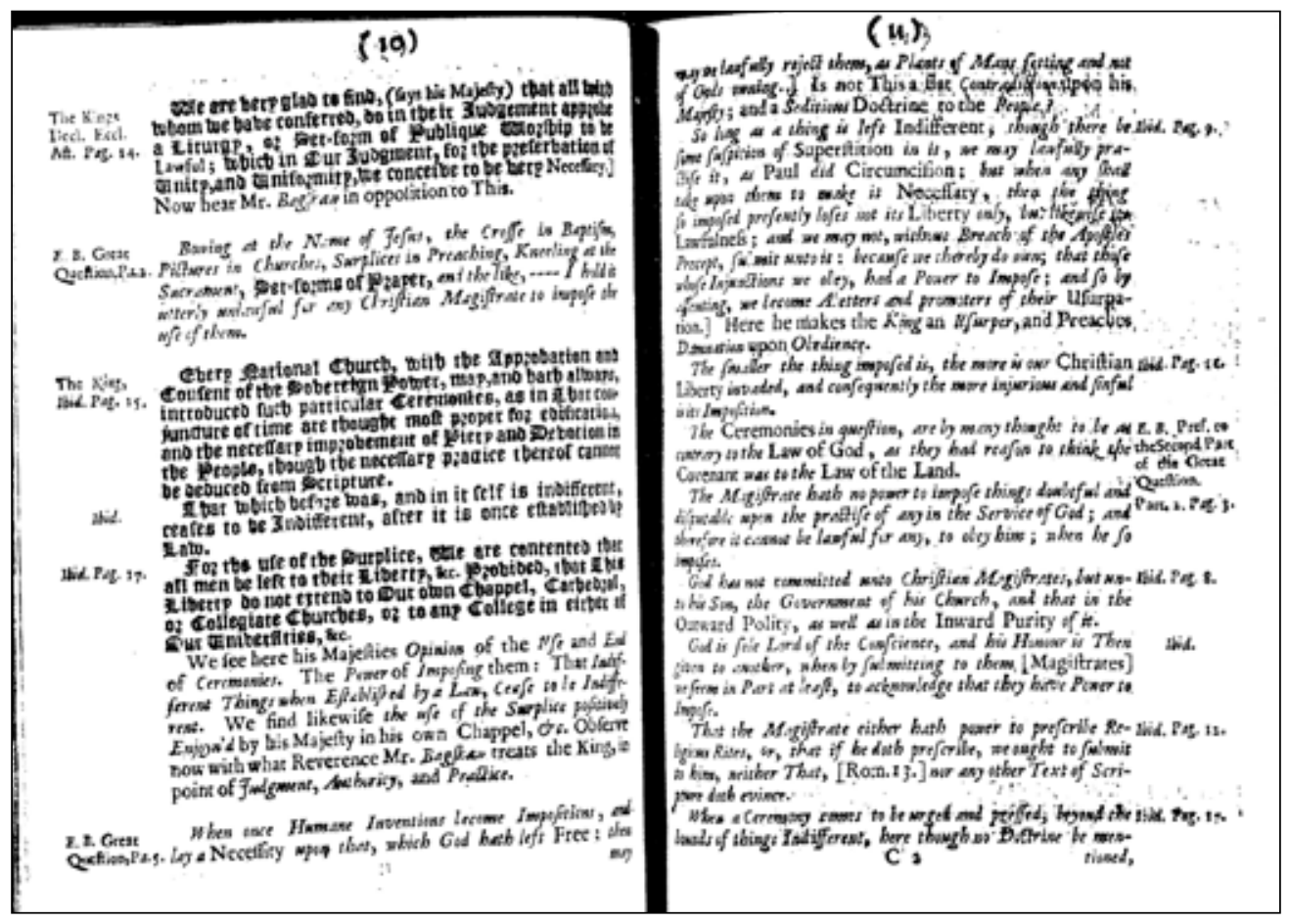

Figura 12 - Páginas de Truth and Loyalty Vindicated (1662)..118

Ao passo em que a black letter utilizada nas palavras de Carlos II realçava e enaltecia a autoridade do soberano para uniformizar a religião, visando suprimir as diversas seitas que haviam se multiplicado durante o contexto revolucionário, a citação de Bagshaw tinha menor destaque, recebendo apenas um itálico, para diferenciá-la da voz de L'Estrange, em romano, nos trechos subsequentes. É interessante observar que a expressão "Formas de Adoração" aparece em gótico também no excerto de Bagshaw, talvez para mostrar uma alusão direta ao discurso do rei. Com a black letter, L'Estrange e Brome uniam as duas citações, colocandoas em confronto para, de um lado, demonstrar a potência da ordenação régia e, de outro, a insolência da sedição proposta pelo fanático Bagshaw.
117. No original: "We are very glad to find, (says his Majesty) that all with whom we have conferred, do in their Judgement approve a Liturgy, or Set-form of Publique Worship to be Lawful; which in Our Judgment, for the preservation of Unity, and Uniformity, we conceive to be very Necessary. Now hear Mr. Bagshaw in opposition to This. / Bowing at the Name of Jesus, the Crosse in Baptism, Pictures in Churches, Surplices in Preaching, Kneeling at the Sacrament, Set-forms of Prayer, and the like, - I bold it utterly unlawful for any Christian Magistrate to impose the use of them." L'Estrange (1662, p. 10).

118. L'Estrange (1662). (C) Cambridge University Library. Imagem produzida pela ProQuest como parte do Early English Books Online e publicada com a permissão da ProQuest. Reproduções sem consentimento são proibidas.

119. Cf. Love (2008). 
Em outras publicações de L'Estrange, a black letter também poderia ser empregada para demarcar índices temáticos. Como observado por Harold Love em suas análises do jornal The Observator, o gótico aparecia apenas em algumas palavras específicas que eram destacadas do restante da página, de modo a orientar a leitura para os diferentes temas abordados por L'Estrange em uma mesma edição. ${ }^{119}$ Esse tipo de função ordenadora parece ser articulada pelo autor-censor e seu livreiro em Considerations and Proposals de 1663. Por ser um panfleto que misturava denúncias a propostas concretas de reforço do Printing Act, a fonte gótica parecia cumprir um papel orientador. Como pode ser visto nas figuras 13 e 14, as palavras "Printing" (Impressão), "Publishing" (Publicação), "Hiding" (Ocultação) e "Concealing" (Dissimulação) foram grafadas em black letter para demarcar os trechos em que cada uma das atividades era abordada. Essa ênfase foi mobilizada em todas as ocorrências dessas palavras nessa seção do panfleto. Além delas, também foram destacadas "Dispersing" (Dispersão), "Private Ware-Houses" (Armazéns Privados) e "Receivers" (Receptores). Os termos em questão referiam-se a fases do processo editorial, bem como às práticas de estacionários sediciosos.

Em Considerations and Proposals, não eram apenas os góticos que exerciam essa função ordenadora. Paralelamente, itálicos foram amplamente utilizados, sobretudo, para destacar agentes do mercado livreiro (por exemplo, "Author", "Compiler", "Writer", "Correcter", "Stationer", "Printer"), tipos de impressos ("Unlawful Pamphlets"), atividades sediciosas e medidas para um controle mais efetivo da imprensa. Notas marginais também aparecem recorrentemente, normalmente sumarizando o conteúdo central dos parágrafos (figuras 13 e 14). Em um texto com teor normatizador, a articulação desses índices era fundamental, pois, ao mesmo tempo em que organizava o texto, reforçava a importância e a urgência das medidas propostas por L'Estrange.

Como vimos nos exemplos anteriores, os usos desses recursos tipográficos não eram estáticos. Quando comparamos diversas publicações de L'Estrange e Brome, há variações no emprego das fontes e dos símbolos. Essas diferenciações podem, inclusive, acontecer dentro de um mesmo texto, como é o caso de Considerations and Proposals, cuja segunda parte era dedicada a listar os textos mais sediciosos do período, a fazer denúncias aos autores e estacionários responsáveis por eles e a demandar a supressão de todos os títulos em questão. Nessa seção do panfleto, as obras perigosas foram organizadas tematicamente, de acordo com os crimes que perpetravam. Os títulos eram indicados em itálico e, abaixo deles, havia uma pequena amostra de seu teor, normalmente uma citação de um a três parágrafos. Quando as ofensas reproduzidas eram muito graves, L'Estrange e Brome as destacavam com fontes góticas. Nas margens, o autor-censor indicava a página da qual havia extraído o excerto e/ou informações adicionais sobre sua impressão e circulação (figura 15). 


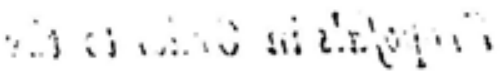

San Marino, California.

Imagem produzida pela ProQuest como parte do Early English Books Online e publicada com a permissão da ProQuest. Reproduções sem consentimento são proibidas.

\section{Confiderations and
In order to the} Regulation

\section{OF THE}
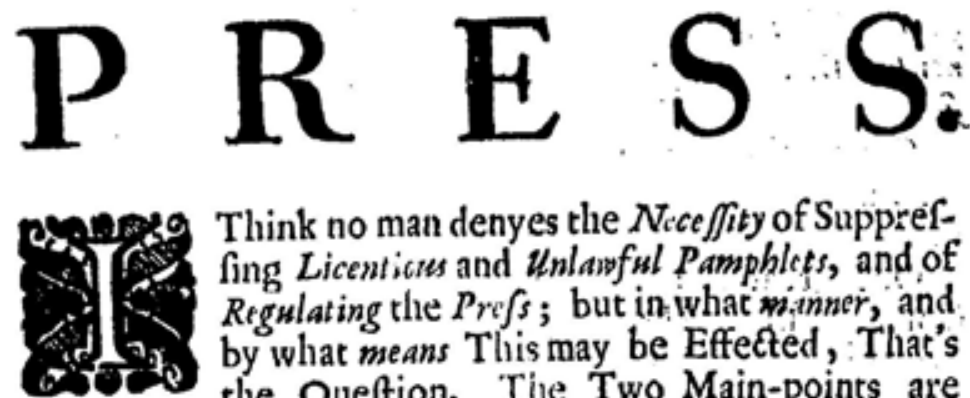

Think no man denyes the Nice/fity of Suppreffing Licenticus and Unlawful Pamphlets, and of Regulating the $P_{r e} / s$; but in what wimner, and by what means This may be Effected, That's the Queftion. The Two Main-points are jezinting, and joublifining.

The Inftruments of fetting the work afoot are Thefe. The Promo- : The Advifer, Author, Compiler, Writer, Correcter, and the, ters, Perfons for whom, and by whom; that is fay, the Stationer (commonly), and the Printer. To which may be $\Lambda$ dded, the Letter-Foundcrs, and the Smiths, and Foyners, that work upon Prefes.

The ufual Agents for publifbing, are the Printers themg and Publihers felves, Stitchers, Binders, Stationers, Hawkers, Mercury-wo- of Pamphless. men, Pedlers, Ballad-fingers, Pojts, Carryers, Hackgey-Codohy men, Bo:t - men, and Mariners. Other Inftruments may: be likewife employ'd, againft whon a General Provifion will be fufficient.

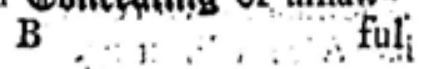

Figura 13 - Páginas de Considerations and Proposals in Order to the Regulation of the Press (1663).120 
Library, San Marino, Califórnia. Imagem produzida pela ProQuest como parte do Early English Books Online e publicada com a permissão da ProQuest. Reproduções sem consentimento são proibidas.

122. Ibid. (C) The Huntington Library, San Marino, Califórnia. Imagem produzida pela ProQuest como parte do Early English Books Online e publicada com a permissão da ProQuest. Reproduções sem consentimento são proibidas.

Figura 15 - Páginas de Considerations and Proposals in Order to the Regulation of the Press (1663). ${ }^{122}$ i

\section{Propofals in Order to the}

fal Books, is but is order to, publitaing, and may be

Touching the Atwifor, Avihur, Conpilin, writer, and Gimder, their Prattices are hated to be Retriv'd, aniefs the

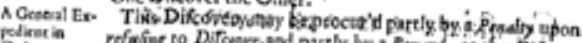

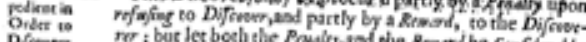

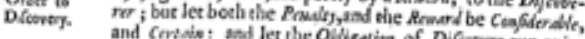
and Cortais: and let the Oilgetina of Dyavery run quire,

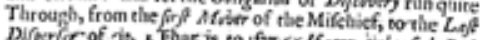

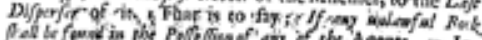
Atromenes afre

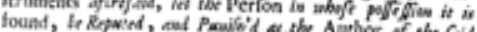

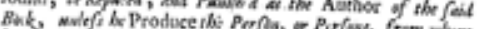

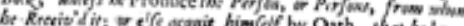

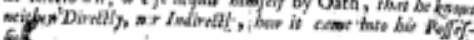

in

Concerning the Confederacy of St-tiewers, and Printers, we halifperk aboa - bet the thing we are now upas in, lingly Deinting, and what neceffarily relares to it.

Malliplicily of One great Evil is the Mraltiplicity of Aributr Proffa, and

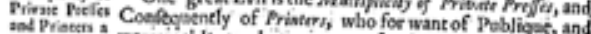
vat Eni. Warrantable enployment, are forc'd either to play the The Renumes in Corners, or to want Bread.

The Reandla The Reandy is, to redace all Prisery, and Prefor, that are notw in Eaployment, to a Limitnd Number ! and tben to provide againat Ptivate Printing for the time to come, Ditowing.

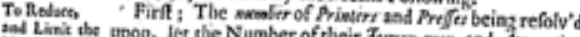

and Linit the upon, Jet the Number of their Juern-mum, and $A$ strowatict

Newha, be likewife Liwited $z$ and in like manner, the Nomber of

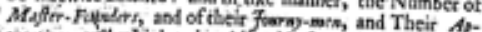
proticos at phich to be Al fich Perforit or Perfons

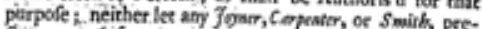

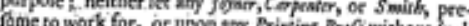

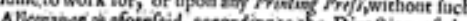
lare Ast for Printing.
Secondly,
Regulatinis of the Prefs.

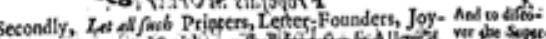

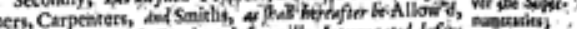

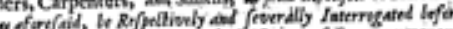
for Prineers and Prefles. That is

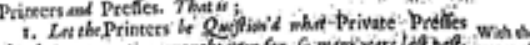

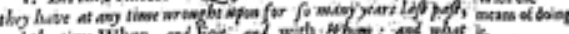

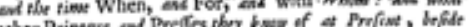
otber Printers and Pretics mo k

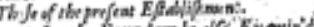
2. Let the Founders le alfo Expmish, mhat Eerter the

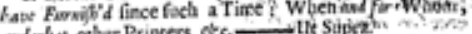

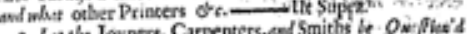
3. Let the Joyners, Carpenters, cel Smiths le Qevflies 2

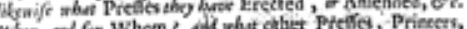

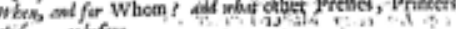

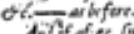

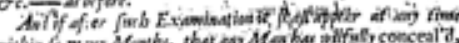

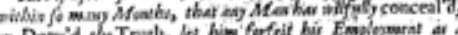

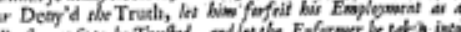

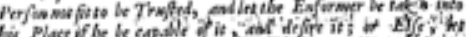

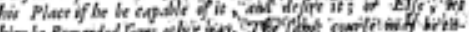

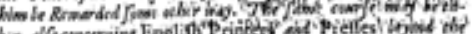

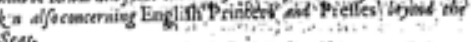
Teas. This may ferre as to the Difcolvety of Pribute Prisisert

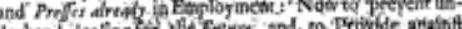

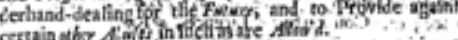

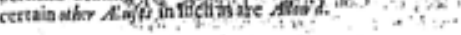

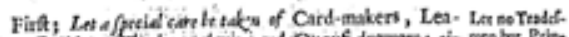
ther-Guilders, Flock-workersy and Quoyf-drawers; ij- men bor Driar

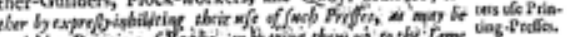

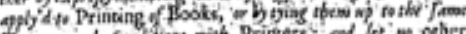

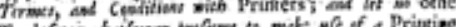

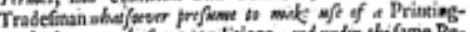

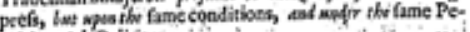
natries sieb' Prïbiers. th:

Figura 14 - Páginas de Considerations and Proposals in Order to the Regulation of the Press (1663).121

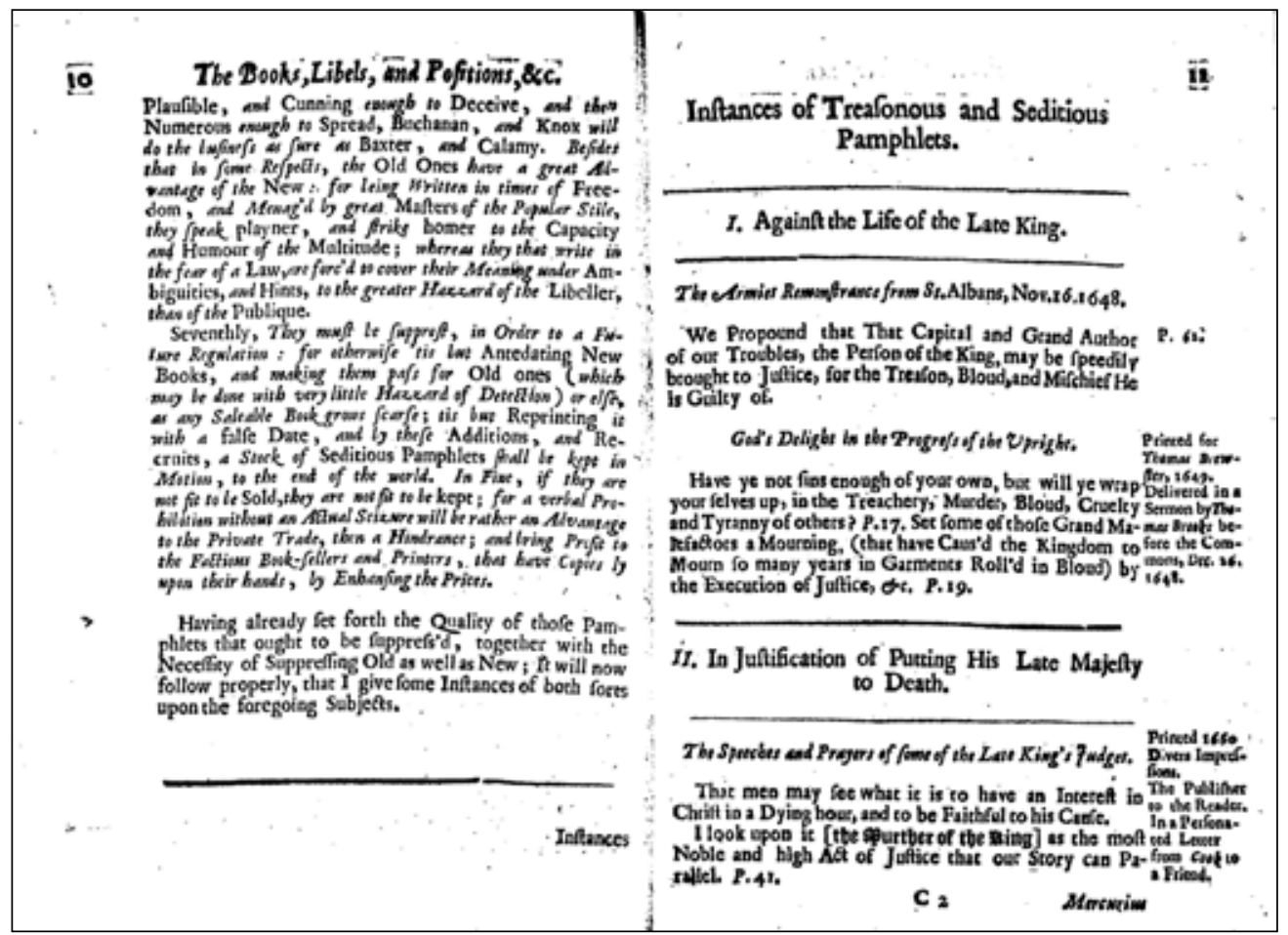


A maioria dessas notas marginais era proveniente de suas investigações contra produtores de literatura sediciosa, incluindo sua empreitada contra os já citados Estacionários Confederados. No item II de sua lista, por exemplo, L'Estrange citava uma das publicações do grupo, The Speeches and Prayers of some of the Late King's Judges, uma compilação de cartas e discursos dos regicidas durante sua execução (figura 14). Embora Carlos II tenha anistiado os crimes cometidos durante o contexto revolucionário, seu perdão não foi concedido àqueles que estiveram diretamente ligados à execução de seu pai, Carlos I. Dez dos regicidas foram executados em outubro de 1660. Logo em seguida, circulava o panfleto dos Confederados, que exaltava os condenados, elevando-os à categoria de mártires da Commonwealth. Para L'Estrange, The Speeches and Prayers ofendia a memória do antigo monarca e justificava seu assassinato ao dizer: "Eu vejo isso [a Morte do Rei] como o mais Nobre e elevado Ato de Justiça que na nossa História pode ter Paralelo. P. 4 1."123

Outros títulos dos Confederados foram mencionados ao longo da lista de L'Estrange. Um exemplo é Mirabilis Annus, citado entre os "Panfletos que manifestadamente tendiam a inflamar as Pessoas contra sua Sagrada Majestade, e o Governo Estabelecido". ${ }^{24}$ Abaixo do título em itálico (figura 16), havia uma reprodução de um trecho da obra, no qual dizia-se que os estranhos acontecimentos relatados no texto foram, anteriormente, prenúncios dos castigos sofridos por aqueles que oprimiram os israelitas. Mirabilis Annus sugeria, assim, que a aparição desses prodígios naquela época era um sinal divino de que Carlos II também padeceria por conta das suas perseguições aos verdadeiros cristãos.

Mais interessante do que a citação oferecida por L'Estrange, era a informação adicionada à margem esquerda, que narrava a trajetória editorial do panfleto (figura 16): "1661. Começado por Tho. Creek para Giles Calvert e Tho. Brewster, e finalizado por Ordem da esposa de Calvert, enquanto seu marido era um Prisioneiro por conta desse mesmo livro." 25 A prisão de Calvert era uma consequência direta dos esforços de L'Estrange para suprimir a literatura sediciosa, iniciados, como vimos, mesmo antes de ser nomeado Surveyor of the Press. $\bigcirc$ comentário marginal, assim, sumarizava e reforçava a empreitada do autor-censor, demonstrando seus sucessos em suprimir textos e estacionários tão perigosos quanto os Confederados. Com essa fala curta, porém assertiva, L'Estrange mostrava que suas denúncias não se resumiam às suas publicações, mas que dependiam também de seu empenho como protetor da ordem, da moral, do governo e da religião. Não é de se estranhar que depois de apresentar tantos sucessos no combate à literatura sediciosa, L'Estrange tenha, de fato, obtido o posto de principal censor do reinado de Carlos $\|$.
123. No original: "I look upon it [the Murther of the King] as the most Noble and high Act of Justice that our Story can Parallel. P. 41.” Ibid., p. 11.

124. No original: "Pamphlets tending manifestly to stir up the People against his Sacred Majesty and the Establish'd Government." Ibid., p. 15

125. No original: "1661. Begun by Tho. Creek for Giles Calvert and Tho. Brewster, and finish'd by the Order of Calverts wife, whilest her husband was a Prisoner for that very book." Ibid., p. 16 
126. Ibid. (C) The Huntington Library, San Marino, California. Imagem produzida pela ProQuest como parte do Early English Books Online e publicada com a permissão da ProQuest. Reproduções sem consentimento são proibidas.

127. Cf. An Exact Narrative... (1664)

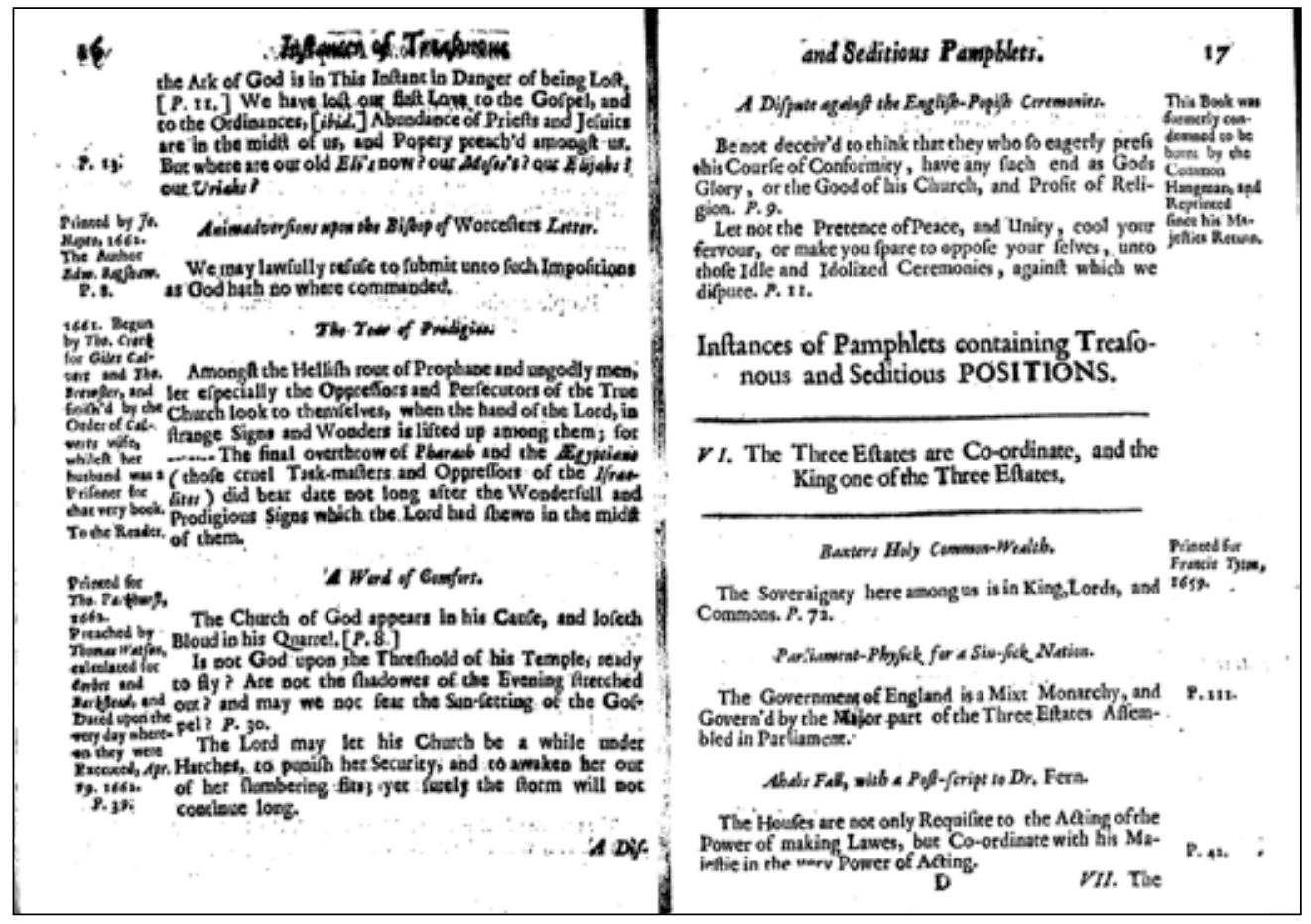

Figura 16 - Páginas de Considerations and Proposals in Order to the Regulation of the Press (1663). ${ }^{126}$

As investidas de Roger L'Estrange contra a literatura clandestina desembocaram na supressão de diversos textos e na prisão dos estacionários responsáveis por sua emissão. No caso de sua luta contra os Confederados, ele levou os principais acusados à corte no início de 1664. Em fevereiro, os livreiros Thomas Brewster e Nathan Brooks e o impressor Simon Dover foram julgados pelo crime de sedição por conta de suas ligações com a produção e a dispersão de The Speeches and Prayers, Mirabilis Annus e A Phenix. Outros estacionários que participaram da publicação, como o impressor Thomas Creake e o encadernador George Thresher, foram ao julgamento apenas na condição de testemunhas, por sua extrema colaboração com as investigações de L'Estrange. Giles Calvert já havia falecido. Livewell Chapman já estava preso. E os três réus foram sentenciados à cadeia, ao pelourinho e ao pagamento de multas. Na mesma ocasião, outro impressor, John Twyn, também ligado ao caso dos Confederados, foi julgado e condenado por alta-traição devido à publicação de $A$ Treatise of the Execution of Justice, sob a encomenda dos Calvert. $\bigcirc$ panfleto defendia um novo regicídio e, por isso, a pena precisava ser mais rigorosa do que a dos demais Confederados. ${ }^{127}$ 
A transcrição do julgamento foi publicada posteriormente por Henry Brome. Embora não conte com o nome de Roger L'Estrange como autor, é muito provável que ele tenha participado do processo de edição do título. Como censor que atuou na investigação, no julgamento e na condenação dos Estacionários Confederados, L'Estrange certamente teve alguma ingerência sobre a publicação. Como parte do sistema de controle, seu nome não precisava constar na folha de rosto. Era mais importante a inscrição "Publicado por AUTORIDADE" 128 logo acima do imprint, que representava aqui não apenas a autoridade para publicar aquele título, mas para examinar, autorizar, suprimir e punir o mercado livreiro (figura 17).

É provável que L'Estrange tenha sido o redator do prefácio de An Exact Narrative of the Tryal and Condemnation of John Twyn, única seção do texto na qual suas maiúsculas e seus itálicos característicos estão presentes, pois no restante da publicação, l'Estrange não aparecia como autor, mas como personagem do evento do julgamento. No prefácio, assumia um tom de repressão e advertência em suas explanações a respeito dos casos e das razões pelas quais aquela transcrição era publicada. Entre outras coisas, ele indicava que o texto servia como "[...] um Aviso a todas as Pessoas que sejam, para que elas possam ver o Perigo da Dispersão de Livros, bem como da Impressão deles [...]". ${ }^{129}$ A punição dos Confederados era exemplar e a publicação de seu caso servia de alerta para os demais agentes do mercado livreiro.

A publicação da transcrição do julgamento mostrava que a censura estava instalada e contava com a potência das ações e palavras de L'Estrange. As normas estavam definidas, desde o Printing Act, e deveriam ser seguidas. Caso contrário, o precedente para condenações severas estava lançado. Era preciso obedecer para não perecer sob o jugo do censor.

Nos anos subsequentes, l'Estrange continuou a desempenhar suas atividades repressoras com afinco. A força com a qual perseguiu estacionários ligados a empreitadas controversas levou, inclusive, a acusações de que cometia abusos. $\bigcirc$ livreiro Francis Smith, que também estivera envolvido com o caso dos Confederados, relatava, em 1680, que Thomas Brewster, Livewell Chapman e Simon Dover morreram na penúria por conta das frequentes prisões e multas que sofreram. $\bigcirc$ livreiro ainda atribuía a L'Estrange diversos prejuízos com materiais e textos apreendidos devido aos assédios do censor, que frequentemente invadia seu estabelecimento. ${ }^{130}$

Por esses excessos, Roger L'Estrange foi criticado e satirizado inúmeras vezes assim que a validade de seu cargo de Surveyor of the Press expirou em 1679. O autor foi retratado como um cão - sempre acompanhado de uma vassoura, em referência ao sobrenome de Brome ("broom"), comumente presa em sua cauda -, que farejava, ladrava e caçava aos outros desmedidamente. Depois
128. No original: "Published by AUTHORITY" Ibid., fl. 1.

129. No original: "[...] a Caution to all Persons whatsoever, that they may see the Hazzard of Dispersing of Books, as well as Printing of them [...]" Ibid., fl. 4v.

130. Smith (1680). 


\section{Cf. Pierce (2010)}

132. (C) Union Theological Seminary (New York, N. Y.). Imagem produzida pela ProQuest como parte do Early English Books Online e publicada com a permissão da ProQuest. Reproduções sem consentimento são proibidas. disso, conseguiu retomar seu posto apenas entre 1685 e 1688, perdendo-o novamente durante o desenrolar da Revolução Gloriosa. ${ }^{131}$

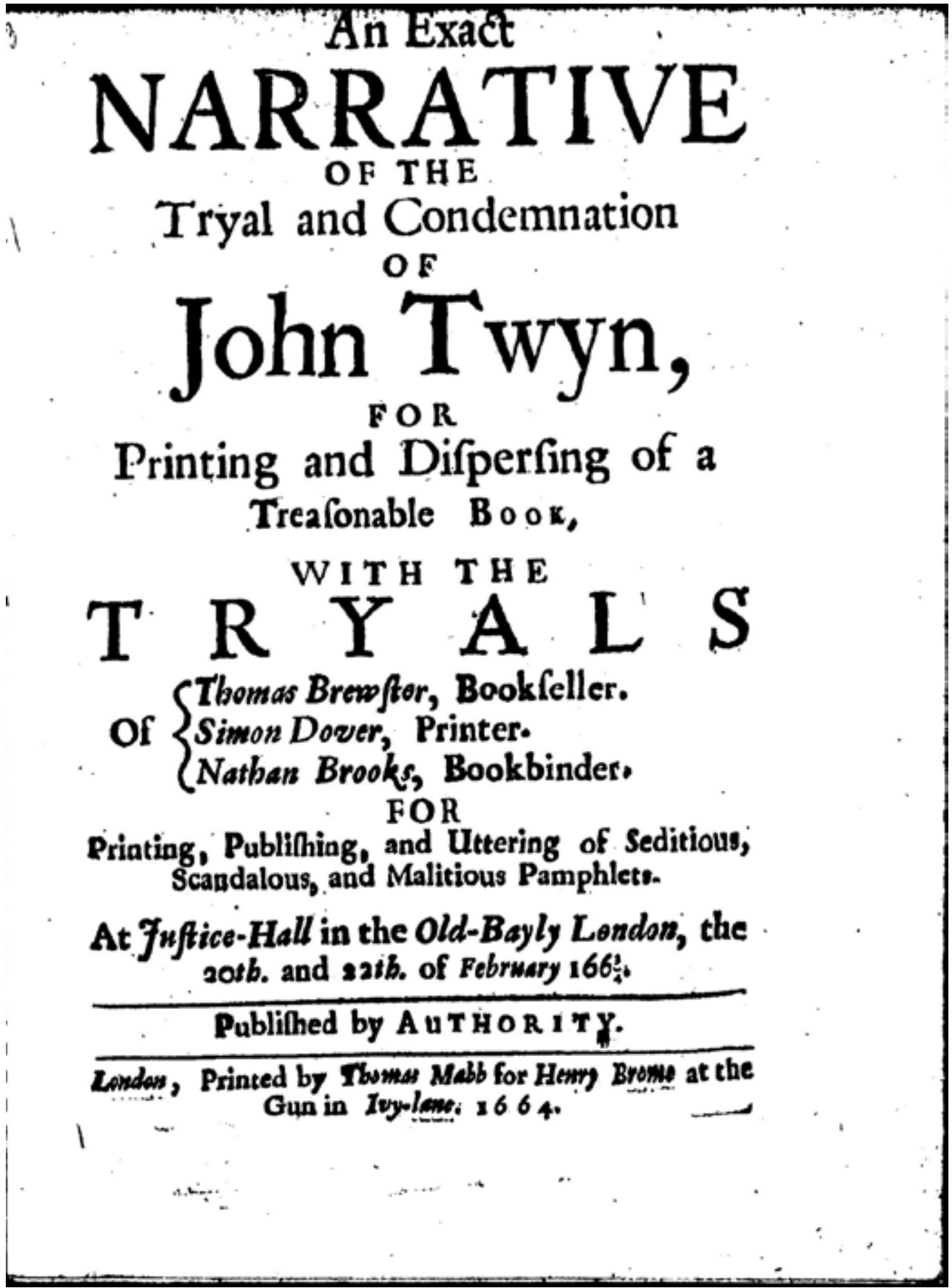

Figura 17 - Folha de rosto de An Exact Narrative of the Tryal and Condemnation of John Twyn... (1664). ${ }^{132}$ 
Embora não tenha sido censor durante todo o tempo em que esteve ativo como escritor, L'Estrange sempre manteve seu engajamento nas questões públicas por meio de seus impressos. Mesmo sem os poderes atribuídos por um título de Surveyor of the Press, suas publicações expressavam um tom repressivo de um leal súdito da monarquia, que zelava pela ordem. A autoridade para sua constante vigia do mercado livreiro era, assim, construída por meio de sua persona autoral, que evocava o officium de censor. A forma e o conteúdo de seus panfletos, por conseguinte, não eram apenas consequências de seu cargo nos sistemas de controle da imprensa, mas condição implícita ao desenvolvimento de sua persona e sua atividade censoras. Seus textos visavam legitimar e reforçar seus posicionamentos nos debates públicos.

Tendo isso em vista, os elementos gráficos de suas composições, facilitadas por Henry Brome, eram tão integrantes de seu discurso quanto suas palavras. Cada itálico, maiúscula, caixa alta, gótico, romano, espaço e símbolo poderia ser empregado com intenções diversas que precisam ser compreendidas juntamente com o conteúdo dos seus escritos. Atentar para esses aspectos é fundamental para compreender textos que eram lidos na Época Moderna, pois os leitores daquele contexto conheciam esses códigos e sabiam como interpretá-los. Não era incomum que os manuais de ortografia ensinassem a ler cada um dos signos que apareciam nos textos impressos, de modo a possibilitar o entendimento, e demonstrar as formas de enunciar os escritos que acessavam. Nesse sentido, ignorar essas dimensões dos livros, panfletos e jornais da Época Moderna é negligenciar muitos de seus significados. ${ }^{133}$

A complexa tipografia mobilizada por L'Estrange e Brome era tal qual muitos dos hipertextos digitais que consumimos atualmente, com símbolos, imagens e sons que se entremeiam e se complementam para construir sentidos. Dessa forma, suas obras eram elaboradas para serem experienciadas de uma maneira profunda e complexa, na qual a multiplicidade de fontes e signos era fundamental. Ao articular a escrita/leitura, a oralidade e a visualidade, esses panfletos buscavam levar o leitor a ver e ouvir acalorados debates com múltiplas vozes, mas dentre as quais a de L'Estrange se sobressaia para mostrar os erros cometidos pelos sediciosos e condená-los em nome da proteção da estabilidade do governo e da religião.

Portanto, a associação entre escrita/leitura, visualidade e oralidade era o que dava potência aos seus discursos, pois provocava diferentes efeitos em seus leitores e/ou ouvintes, visando convencê-los de suas posições. Assim, sua elaborada tipografia era retórica. Ela saltava aos olhos do público, conduzindo-o pelas páginas numa tentativa de controlar suas interpretações. Exercendo seu papel de autor-censor, L'Estrange parecia se armar com o Canhão da livraria de Henry Brome para dominar sua audiência, destruir seus adversários e suprimir os sediciosos.
133. Cf., por exemplo, Price (1670). 


\section{REFERÊNCIAS}

FONTES MANUSCRITAS

Public Records Office, State Papers, Domestic. PRO SP29/28/121.

Public Records Office, State Papers, Domestic. PRO SP29/28/121a.

Public Records Office, State Papers, Domestic. PRO SP29/38/123

Public Records Office, State Papers, Domestic. PRO SP29/38/124.

Public Records Office, State Papers, Domestic. PRO SP29/51/13.

Public Records Office, State Papers, Domestic. PRO SP29/78/182.

FONTES IMPRESSAS

A PHENIX, or, The Solemn League and Covenant. Edinburgh: printed in the year of covenantbreaking [1661].

AN EXACT Narrative of the Tryal and Condemnation of Jobn Twyn, for Printing and Dispersing of a Treasonable Book, with the Tryals of Thomas Brewster, Bookseller. Simon Dover, Printer. Nathan Brooks, Bookbinder... London, Printed by Thomas Mabb for Henry Brome at the Gun in Ivy-lane. 1664.

BY THE KING. A proclamation for calling in, and suppressing of two books written by John Milton; the one intituled, Johannis Miltoni Angli pro populo Anglicano defensio, contra Claudii Anonymi aliàs Salmasii, defensionem regiam; and the other in answer to a book intituled, The pourtraicture of His Sacred Majesty in his solitude and sufferings. And also a third book intituled, The obstructors of justice, written by John Goodwin. London: printed by John Bill and Christopher Barker, printers to the Kings most Excellent Majesty, 1660.

CHARLES II. An Act for preventing the frequent Abuses in printing seditious treasonable and unlicensed Bookes and Pamphlets and for regulating of Printing and Printing Presses. In: 
CORBET, John. The interest of England in the matter of religion unfolded in the solution of these three questions... London: Printed by J.M. for G.T. and are to be sold at the Rose and Crown in St Pauls Church-yard, 1660.

EDWARDS, Thomas. Gangrana: or A catalogue and discovery of many of the errours, heresies, blasphemies and pernicious practices of the sectaries of this time, vented and acted in England in these four last years... London: Printed for Ralph Smith, at the signe of the Bible in Corn-hill near the Royall-Exchange, 1646.

ENIAYTOS terastios Mirabilis annus, or, The year of prodigies and wonders, being a faithful and impartial collection of severall signs that have been seen in the heavens, in the earth, and in the waters... [s. l.]: [s. n.], 1661.

GRIFFITH, Matthew. The fear of God and the King. Press'd in a sermon, preach'd at Mercers Chappell, on the 25th. of March, 1660. London: Printed for Tho: Johnson at the Golden Key in St. Pauls Church-yard, 1660.

L'ESTRANGE, Roger. A Modest Plea Both for the Caveat, and The Author of It. With Some Notes Upon Mr. James Howell, and His Sober Inspections. London, For Henry Brome at the Gun in Ivy lane. Printed Aug. 28. 1661b.

L'ESTRANGE, Roger. A short view of some remarkable transactions, leading to the happy settlement of these nations under the government of our lawfull and gracious soveraign, Charl[e] s the II, whom God preserve by Roger L'Estrange. London: Printed for Henry Brome..., 1660b.

L'ESTRANGE, Roger. Considerations and proposals in order to the regulation of the press: together with diverse instances of treasonous, and seditious pamphlets, proving the necessity thereof. By Roger L'Estrange. London: printed by A.C., June 3d. M.DC.LXIII. [1663].

L'ESTRANGE, Roger. Interested Mistaken, Or, The Holy Cheat... London, Printed for Henry Brome, at the Gun in Ivy-lane. 1661a.

L'ESTRANGE, Roger. L'Estrange his apology: with a short view, of some late and remarkable transactions, leading to the happy settlement of these nations under the government of our lawfull and gracious soveraign Charls the II. London: Printed for Henry Brome, at the Gun in Ivy-Lane, 1660a.

L'ESTRANGE, Roger. L'Estrange his vindication from the calumnies of a malitious party in Kent (relating to a commotion there in May 1648) which hee [sic] addresses to the authours and promoters of them. [London: $s . n$.], printed in the yeer 1649. 
L'ESTRANGE, Roger. No Blinde Guides, In Answer To a seditious Pamphlet of J. Milton's... London, Printed for Henry Brome April 20. 1660c.

L'ESTRANGE, Roger. The Observator, n. 340. London, Printed by Joanna Brome at the Gun in St. Pauls Church-yard, 17 May. 1683.

L'ESTRANGE, Roger. To the right honorable Edward Earl of Clarenden, Lord High Chancellor of England, the humble apology of Roger L'Estrange. London : printed for Henry Brome..., M. DC. LXI. [1661c].

L'ESTRANGE, Roger. Truth and loyalty vindicated, from the reproches and clamours of Mr. Edward Bagshaw. London: printed for H. Brome, and A. Seile, and are to be sold at the Gun in Ivy-lane, and over against St. Dunstans Church in Fleetstreet, June the 7th. 1662.

MARVELL, Andrew. An essay, or, A narrative of the two great fights at sea between the English and the Dutch, on the 1, 2, 3 and 4 of June, and on the 25 and 26 of July in the year of our Lord 1666. London: Printed by E.C. for Henry Brome..., 1666.

MILTON, John. Brief notes upon a late sermon, titl'd, The fear of God and the King preach'd, and since publish'd by Matthew Griffith... wherin many notorious wrestings of Scripture, and other falsities are observed / by J.M. London: [s. n.], 1660.

MILTON, John. The readie \& easie vvay to establish a free Commonwealth, and the excellence therof compar'd with the inconveniences and dangers of readmitting kingship in this nation. London: printed by T.N. and are to be sold by Livewell Chapman at the Crown in Popes-Head-Alley, 1660a.

MOXON, Joseph. Mechanick exercises: or, the doctrine of handy-works. Applied to the art of printing. The second volumne [sic]. By Joseph Moxon, member of the Royal Society, and bydrographer to the King's most excellent majesty. London: printed for Joseph Moxon on the west-side of Fleet-ditch, at the sign of Atlas, 1683.

PRICE, Owen. English Ortographie: Teaching, I. The Letters of every sort of Print. II. All Syllables made of Letters. III. Short Rules by way of Question and Answer for Spelling, Reading, Pronouncing, using the Great Letters and the Points... Oxford: Printed by L. Lichfield for Francis Tyton at the Three Daggers in Fleetstreet London, 1670.

PRYNNE, William. The re-publicans and otbers spurious good old cause, briefly and truly anatomized. London: [s. n.], 1659.

RAITHBY, John (ed). Statutes of the Realm: Volume 5, 1628-80. [s. l.]: Great Britain Record Commission, 1819. Disponível em: <https://bit.ly/2Ulygsy>. Acesso em: 31 mar. 2020. 
ROGERS, John. Diapoliteia. A Christian concertation with Mr. Prin, Mr. Baxter, Mr. Harrington, for the true cause of the Commonvvealth. London: printed for Livewel Chapman, at the Crown in Popes-Head-Alley, 1659.

SMITH, Francis. An account of the injurious proceedings of Sir George Jeffreys, Knt., late recorder of London, against Francis Smith, bookseller with his arbitrary carriage towards the grand-jury at Guild-Hall, Sept. 16, 1680... London: Printed for Francis Smith..., [1680].

LIVROS, ARTIGOS E TESES

ACHINSTEIN, Sharon. Texts in conflict: the press and the Civil War. In: KEEBLE, N. H. (ed.). The Cambridge Companion to Writing of the English Revolution. Cambridge: Cambridge University Press, 2006.

ARAÚJO, André de Melo. O conhecimento impresso: Práticas editoriais e estratégias comerciais nos manuais de impressão da Época Moderna. Varia Historia, v. 36, n. 70. p. 53-90, 2020.

BAKER, P. R. S. Edwards, Thomas (c. 1599-1648), Church of England clergyman and religious controversialist. Oxford Dictionary of National Biography. Oxford: Oxford University Press, 2004. Disponível em: <https://doi.org/10.1093/ref:odnb/8556>. Acesso em: 31 mar. 2020.

BARNARD, John; MCKENZIE, D.F.; BELL, Maureen (eds.). The Cambridge History of the Book in Britain. V. 4. Cambridge: Cambridge University Press, 2002.

BELL, Maureen. Elizabeth Calvert and the "Confederates". Publishing History, Jan. 1, n. 32, 1992, p. 5-49.

BIRRELL, T. A. Sir Roger L'Estrange: the journalism of orality. In: BARNARD, John; MCKENZIE, D.F.; BELL, Maureen (eds.). The Cambridge History of the Book in Britain. V. 4. Cambridge: Cambridge University Press, 2002.

BOUZA, Fernando. Comunicação, Conhecimento e Memória na Espanha dos séculos XVI e XVII. Cultura, n. 14, 2002.

CAMPBELL, Gordon. Milton, John (1608-1674), poet and polemicist. Oxford Dictionary of National Biography. Oxford: Oxford University Press, 2009. Disponível em: <https://doi. org/10.1093/ref:odnb/18800>. Acesso em: 31 mar. 2020.

CHARTIER, Roger (org.). Práticas da Leitura. São Paulo: Estação Liberdade, 2011. 
CHARTIER, Roger. A mão do autor e a mente do editor. São Paulo: Unesp, 2014.

CLEGG, Cyndia Susan. Press Censorship in Caroline England. Cambridge: Cambridge University Press, 2010.

DAVIS, Herbert Davis; CARTER, Harry Carter. Introduction. In: MOXON, Joseph. Mechanick Exercises on the Whole Art of Printing, 1683-4. Londres: Oxford University Press, 1958.

DZELZAINIS, Martin. Managing the Later Stuart Press, 1662-1696. In: HUTSON, Lorna (ed). The Oxford Handbook of English Law and Literature, 1500-1700. Oxford: Oxford University Press, 2017.

GREAVES, Richard L. Rogers, John (b. 1627), Fifth Monarchist writer. Oxford Dictionary of National Biography. Oxford: Oxford University Press, 2008. Disponível em: <https://doi. org/10.1093/ref:odnb/23983>. Acesso em: 31 mar. 2020.

GREAVES, Richard L. Deliver us from evil: the radical underground in Britain, 1660-1663. Oxford: Oxford University Press, 1986.

HAMBURGER, Philip. The Development of the Law of Seditious Libel and the Control of the Press. Stanford Law Review, v. 37, n. 3, p. 661-765, 1985.

HANSEN, João Adolfo. Barroco, neobarroco e outras ruínas. Entrevista concedida a Joaci Pereira Furtado. Cult: Revista Brasileira de Literatura, n. 10, p. 10-66, 1998.

HARRIS, Tim. Restoration: Charles II and his kingdoms, 1660-1685. Londres: Penguin, 2006.

HILL, Christopher. O Mundo de Ponta-Cabeça: idéias radicais durante a Revolução Inglesa de 1640. São Paulo: Companhia das Letras, 1987.

HILL, Christopher. O Século das Revoluções, 1603-1714. São Paulo: Unesp, 2012.

HUTTON, Ronald. The Restoration: a political and religious history of England and Wales 1658-1667. Oxford: Oxford University Press, 2001.

JOHNS, Adrian. The Nature of the Book: Print and Knowledge in the Making. Chicago: University of Chicago Press, 1998. 
KEEBLE, N. H. (ed.). The Cambridge Companion to Writing of the English Revolution. Cambridge: Cambridge University Press, 2001.

KEEBLE, N. H. The Restoration: England in the 1660s. Cornwall: Blackwell, 2002.

KITCHIN, George. Sir Roger L'Estrange: a contribution to the history of the press in the seventeenth century. Nova York: Augustus M. Kelley, 1971.

LAMONT, William. Prynne, William (1600-1669), pamphleteer and lawyer. Oxford Dictionary of National Biography. Oxford: Oxford University Press, 2011. Disponível em: <https://doi. org/10.1093/ref:odnb/22854>. Acesso em: 31 mar. 2020.

LANDER, Jesse M. Inventing Polemic: religion, print and literary culture in Early Modern England. Cambridge: Cambridge University Press, 2006.

LESSER, Zachary. Typographic Nostalgia: Playreading, Popularity, and Black Letter. In: STRAZNICKY, Marta (ed.). The Book $f$ the Play: Playwrights, Stationers, and Readers in Early Modern England. Amherst: University of Massachusetts Press, 2006.

LIMA, Verônica Calsoni. "Impresso para ser vendido na Crown em Pope's Head Alley": Hannah Allen, Livewell Chapman e a disseminação de panfletos radicais religiosos durante a Revolução Inglesa (1646-1665). Dissertação (Mestrado em História) - Escola de Filosofia, Letras e Ciências Humanas da Universidade Federal de São Paulo, São Paulo, 2016.

LOVE, Harold. L'Estrange, Joyce and the Dictates of Typography. In: DUNAN-PAGE, Anne; LYNCH, Beth (eds.). Roger L'Estrange and the Making of Restoration Culture. Londres: Routledge, 2008.

LOVE, Harold. L'Estrange, Sir Roger (1616-1704), author and press censor. Oxford Dictionary of National Biography. Oxford: Oxford University Press, 2007. Disponível em: <https://doi. org/10.1093/ref:odnb/16514>. Acesso em: 31 mar. 2020.

LYNCH, Beth. Rhetoricating and Identity in L'Estrange's Early Career, 1659-1662. In: DUNAN-PAGE, Anne; LYNCH, Beth (eds.). Roger L'Estrange and the Making of Restoration Culture. Londres: Routledge, 2008.

MALTZAHN, Nicholas von. Brome, Henry (d. 1681), bookseller. Oxford Dictionary of National Biography. Oxford: Oxford University Press, 2004. Disponível em: <https://doi.org/10.1093/ ref:odnb/69222>. Acesso em: 31 mar. 2020. 
MCELLIGOTT, Jason. The Book Trade, Licensing, and Censorship. In: KNOPPERS, Laura (ed.). The Oxford Handbook of Literature and the English Revolution. Oxford: Oxford University Press, 2012.

MCKENZIE, D. F. Bibliography and The Sociology of Texts. Cambridge: Cambridge University Press, 2004.

MOLLIER, Jean-Yves. A história do livro e da edição: um observatório privilegiado do mundo mental dos homens do século XVIII ao século XX. Varia História, Belo Horizonte, v. 25, n. 42, 2009, p. 521-537.

NOGUEIRA, Patrícia Moreira. "Um Catálogo De Erros Agora Em Voga": Ortodoxia Presbiteriana, Intertextualidade e Confessionalização na obra Gangraena (1646) de Thomas Edwards. Dissertação (Mestrado em História) - Escola de Filosofia, Letras e Ciências Humanas da Universidade Federal de São Paulo, São Paulo, 2017.

OSTRENSKY, Eunice. As revoluções do poder. São Paulo: Alameda, 2005.

PIERCE, Helen. The Devil's Bloodhound: Roger L'Estrange Caricatured. In: HUNTER, Michael (ed.). Printed Images in Early Modern Britain: Essays in Interpretation. Londres: Routledge, 2010.

PUJOL, Francisco Xavier Gil. Crónica y cuestiones de veinticinco años de debate. Revista Pedralbes, n. 17, 1997, p. 241-288.

RAVEN, James. What is the History of the Book? (What is History?). Cambridge/Malden: Polity Press 2017. [e-book]

RAYMOND, Joad. Censorship in Law and Practice in Seventeenth-Century England. In: HUTSON, Lorna (ed). The Oxford Handbook of English Law and Literature, 1500-1700. Oxford: Oxford University Press, 2017.

RAYMOND, Joad. Pamphlets and Pamphleteering in Early Modern Britain. Cambridge: Cambridge University Press, 2004.

RICHARDSON, R. C. The debate on the English Revolution. Manchester: Manchester University Press, 1998.

RUSSEL, Conrad (ed.). The Origins of the Civil War. Londres: Macmillan, 1973. 
SANTOS JUNIOR, Jaime Fernando dos. John Rogers e a disputa pela Commonwealth: debates e polêmicas com William Prynne, Richard Baxter e James Harrington, durante a segunda república inglesa. Dissertação (Mestrado em História) - Escola de Filosofia, Letras e Ciências Humanas da Universidade Federal de São Paulo, São Paulo, 2014.

SMITH, Nigel. Literature E Revolution in England, 1640-1660. New Haven: Yale University Press, 1997.

STONE, Lawrence. Causas da Revolução Inglesa, 1529-1642. Bauru: Edusc, 2000.

TAYLOR, Darrick N. L'Estrange his life: public and persona in the life and career of Sir Roger L'Estrange, 1616-1704. Tese (Doutorado em História) - Universidade de Kansas, Lawrence, 2011.

THOMAS, Keith. The Meaning of Literacy in Early Modern England. In: BAUMANN, Gerd. The Written Word: Literacy in Transition. Oxford: Clarendon Press, 1986.

WATT, Tessa. Cheap Print and Popular Piety, 1550-1640. Cambridge: Cambridge University Press, 1996.

WOOLF, D. R. Howell, James (1594?-1666), historian and political writer. Oxford Dictionary of National Biography. Oxford: Oxford University Press, 2008. Disponível em: <https://doi. org/10.1093/ref:odnb/13974>. Acesso em: 31 mar. 2020.

WOOLRYCH, Austin. Britain in Revolution, 1625-1660. Oxford: Oxford University Press, 2002.

WORDEN, Blair. The English Civil Wars: 1640-1660. Londres: Phoenix, 2009.

SITES

BRITISH History Online. Disponível em: <http://www.british-history.ac.uk>. Acesso em: 31 mar. 2020.

EARLY Modern English Books Online. Disponível em: <https://search.proquest.com/eebo>. Acesso em: 31 mar. 2020.

JENSTAD, Janelle (ed.). The Early Modern London. v. 6.3. Victoria, BC: University of Victoria, 2018. Disponível em: <https://mapoflondon.uvic.ca>. Acesso em: 4 mar. 2020. 
OXFORD Dictionary of National Biographies. Disponível em: <https://www.oxforddnb. com/>. Acesso em: 31 mar. 2020.

Artigo apresentado em 4/4/2020. Aprovado em 4/5/2020.

\section{(cc) BY}

All the contents of this journal, except where otherwise noted, is licensed under a Creative Commons Attribution Licens 